\title{
A new method of deriving time-averaged tropospheric column ozone over the tropics using total ozone mapping spectrometer (TOMS) radiances: Intercomparison and analysis using TRACE A data
}

\author{
J. H. Kim ${ }^{1}$ and R. D. Hudson ${ }^{2}$ \\ Department of Meteorology, University of Maryland, College Park
}

\author{
A. M. Thompson ${ }^{2}$ \\ NASA Goddard Space Flight Center, Greenbelt, Maryland
}

\begin{abstract}
Error analysis of archived total $\mathrm{O}_{3}$ from total ozone mapping spectrometer (TOMS) (version 6) presented in earlier studies [Hudson and Kim, 1994; Hudson et al., 1995 ] is extended to include scan angle effects. Daily total $\mathrm{O}_{3}$ maps for the tropics, from the period October 6-21, 1992, are derived from TOMS radiances following correction for these errors. These daily maps, averaged together, show a wavelike feature, which is observed in all latitude bands $\left(10^{\circ} \mathrm{N}\right.$ to $\left.14^{\circ} \mathrm{S}\right)$, underlying sharp peaks which occur at different longitudes depending on the latitude. The wave pattern is used to derive both time-averaged stratospheric and tropospheric $\mathrm{O}_{3}$ fields. The nature of the wave pattern (stratospheric or tropospheric) cannot be determined with certainty due to missing data (no Pacific sondes, no lower stratospheric Stratospheric Aerosol and Gas Experiment (SAGE) ozone for 18 months after the Mt. Pinatubo eruption) and significant uncertainties in the corroborative satellite record in the lower stratosphere (solar backscattered ultraviolet (SBUV), microwave limb sounder (MLS)). However, the timeaveraged tropospheric ozone field, based on the assumption that the wave feature is stratospheric, agrees within $10 \%$ with ultraviolet differential absorption laser Transport and Atmospheric Chemistry near the Equator-Atlantic) (TRACE A) $\mathrm{O}_{3}$ measurements from the DC-8 [Browell et al., this issue] and with ozonesonde measurements over Brazzaville, Congo $\left(4^{\circ} \mathrm{S}, 15^{\circ} \mathrm{E}\right)$, Ascension Island $\left(8^{\circ} \mathrm{S}, 15^{\circ} \mathrm{W}\right)$, and Natal, Brazil $\left(5.5^{\circ} \mathrm{S}\right.$, $35^{\circ} \mathrm{W}$ ), for the period October 6-21, 1992. The derived background (nonpolluted) Indian Ocean tropospheric ozone amount, 26 Dobson units (DU), agrees with the cleanest African ozonesonde profiles for September-October 1992. The assumption of a totally tropospheric wave (flat stratosphere) gives 38 DU above the western Indian Ocean and $15-40 \%$ disagreements with the sondes. Tropospheric column $\mathrm{O}_{3}$ is high from South America to Africa, owing to interaction of dynamics with biomass burning emissions [Thompson et al., this issue $(\mathrm{a}, \mathrm{b})]$ ] Comparison with fire distributions from advanced very high resolution radiometer (AVHHR) during October 1992 suggests that tropospheric $\mathrm{O}_{3}$ produced from biomass burning in South America and Africa dominates the $\mathrm{O}_{3}$ budget in the tropical southern hemisphere during the study period.
\end{abstract}

\section{Introduction}

Tropospheric ozone plays an important role in both tropospheric oxidation and global climate change and as a pollutant. Because ground-based measurements of tropospheric ozone give limited data in time and space, space-based measurements are in demand. Fishman and coworkers [Watson et al., 1991; Fishman, 1991; Fishman et al., 1991] developed the concept of a tropospheric "residual" to determine time-averaged tropo-

\footnotetext{
${ }^{1}$ Now at Earth System Science Laboratory, University of Alabama, Huntsville.

${ }^{2}$ Also at Joint Center for Earth System Science, University of Maryland, College Park.

Copyright 1996 by the American Geophysical Union.

Paper number 96JD01223. 0148-0227/96/96JD-01223\$09.00
}

spheric column $\mathrm{O}_{3}$ by subtracting stratospheric column $\mathrm{O}_{3}$, obtained from the Stratospheric Aerosol and Gas Experiment (SAGE), from total ozone mapping spectrometer (TOMS) total $\mathrm{O}_{3}$. Archived, gridded TOMS total $\mathrm{O}_{3}$ data with $1^{\circ} \times$ $1.25^{\circ}$ resolution (version 5 , later version 6 ) was used for these studies. The tropospheric $\mathrm{O}_{3}$ residual maps showed enhanced $\mathrm{O}_{3}$ over the Atlantic off the coast of west Africa during the biomass burning season. This result drew great attention to tropical tropospheric chemistry.

However, Thompson et al. [1993], Hudson and Kim [1994], and Hudson et al. [1995] have shown that the use of the archived TOMS total $\mathrm{O}_{3}$ data from the current TOMS algorithm introduces an overestimation of total ozone over stratocumulus clouds by as much as 20 Dobson units (DU), and an underestimation of total ozone up to 15 DU when extremely high amounts of low-lying tropospheric $\mathrm{O}_{3}$ are present. Since these conditions prevail over southern Africa and the adjacent At- 
lantic during the biomass burning season, Hudson et al. [1995] suggested that the contrast in residual-derived tropospheric ozone between the Atlantic and the African continent is exaggerated. In addition, unlike TOMS, which provides a daily global total ozone map with $50 \times 50 \mathrm{~km}$ resolution, the spatial coverage of SAGE is limited to two latitude bands a day with 15 measurements each. These are $25^{\circ}$ longitude apart; latitude coverage is from $70^{\circ} \mathrm{N}$ to $70^{\circ} \mathrm{S}$ over a period of approximately 1 month [McCormick et al., 1989]. Therefore significant differences in spatial and temporal resolution between the two data sets can lead to an error in determining time-averaged tropospheric ozone for a short timescale.

This paper presents a new method to overcome these difficulties in determining time-averaged tropospheric column $\mathrm{O}_{3}$ in the tropics using only TOMS radiances. Since the archived TOMS total $\mathrm{O}_{3}$ (version 6) has errors associated with clouds, low retrieval efficiency of tropospheric ozone, Pinatubo aerosols [Bhartia et al., 1993], and the determination of the spacecraft attitude [Aerospace Engineering and Research Associates $(A E R A), 1990]$, we have used TOMS radiances to correct these errors (section 2). Section 3 shows a new method to derive time-averaged stratospheric and tropospheric $\mathrm{O}_{3}$ fields over the entire tropical band using only TOMS data and sondes. The error analysis of this method is discussed in section 4 . The time-averaged tropospheric column $\mathrm{O}_{3}$ derived using the new method is then compared with ozonesonde and ultraviolet differential absorption laser (uv-DIAL) ozone measurements over the South Atlantic basin (section 5). Finally, features of the tropospheric $\mathrm{O}_{3}$ budget over the tropics during October 1992 are discussed (section 6).

The period of study is October 6 to 21, 1992, which is of interest because of South Atlantic field experiments: Southern Tropical Atlantic Regional Experiment (STARE) Southern African Fire Atmospheric Research Initiative (SAFARI) and Transport and Atmospheric Chemistry near the EquatorAtlantic (TRACE A), in September and October 1992 [Andreae et al., 1994a; Fishman et al., this issue (a)].

\section{Corrections to Archived Total Ozone From TOMS}

The TOMS instrument scans across a track perpendicular to the spacecraft velocity vector in 35 sequential scan positions [McPeters et al., 1993]. Scan positions 1, 18, and 35 correspond to the highest scan angle to the right, the nadir angle, and the highest scan angle to the left, respectively. The coverage for one cross track corresponds to about $26^{\circ}$ longitude at the equator, and thus it takes about 14 orbits per day to cover the entire globe. The 14 orbits actually cover about $365^{\circ}$, so the nadir track shifts $5^{\circ}$ westward each day. Figure 1a shows archived total $\mathrm{O}_{3}$ from the high-density tapes over the tropics for October 1 and 2, 1992. The total $\mathrm{O}_{3}$ distribution shows three maxima at $178^{\circ} \mathrm{E}, 156^{\circ} \mathrm{W}$, and $132^{\circ} \mathrm{W}$, about $26^{\circ}$ apart, which shift westward about $5^{\circ}$ on the following day. Because the number of maxima, the interval between maxima, and the motion of maxima exactly match, respectively, the number of the satellite orbits, TOMS coverage for each orbit, and orbit shift, these maxima most likely represent an apparent TOMS scan bias.

Two factors contribute to this bias: (1) an error due to scattering by stratospheric aerosols in the stratosphere arising from the Mt. Pinatubo eruption [Bhartia et al., 1993] and (2) an error in the Nimbus 7 satellite roll angle $[A E R A, 1990]$. As the satellite roll angle changes, so does the effective scan angle at the Earth. The error in the derived total $\mathrm{O}_{3}$ is more at the extreme off-nadir positions ( 1 and 35 ) than at the nadir position (18) because path length changes as the secant of the angle [McPeters et al., 1993]. In order to determine the error in the derived total $\mathrm{O}_{3}$ due to the attitude error, we averaged the measured total $\mathrm{O}_{3}$ under clear sky conditions (reflectivity less than 0.2 ) as a function of scan position over the tropics in October 1989 prior to the Mt. Pinatubo eruption. Figure 2a shows the averaged total $\mathrm{O}_{3}$ in each scan position relative to that in scan position 18, where the $\mathrm{O}_{3}$ error is negligible [ $\mathrm{Mc}$ Peters et al., 1993]. Total $\mathrm{O}_{3}$ is underestimated at the right scan position (1-17) and overestimated at the left scan position $(19-35)$.

The error due to stratospheric aerosols arises because the TOMS algorithm assumes that only Rayleigh scattering occurs. In order to account for this error, we averaged the measured total $\mathrm{O}_{3}$ for clear sky conditions as a function of scan position from October 6 to 21, 1992. Because the averaged total $\mathrm{O}_{3}$ in 1992 contains both the attitude error and the aerosol error, the attitude error derived above is first subtracted from the averaged total $\mathrm{O}_{3}$. The error due to aerosols in the stratosphere has been shown to be negligible at scan position 1 [Bhartia et al., 1993]. Hence we can derive the aerosol error by subtracting the corrected total $\mathrm{O}_{3}$ at scan position 1 from the total $\mathrm{O}_{3}$ at the other scan positions (Figure $2 \mathrm{~b}$ ). Figure $2 \mathrm{c}$ is the total error as a function of scan angle. The total error is subtracted from the derived total $\mathrm{O}_{3}$ to obtain corrected total $\mathrm{O}_{3}$ (see Figure $1 \mathrm{~b}$ ). Note that the scan bias has been eliminated.

\section{A New Algorithm to Determine Time- Averaged Stratospheric and Tropospheric Column Ozone}

Ideally, in order to retrieve the tropospheric column $\mathrm{O}_{3}$ using only TOMS radiances, we require a knowledge of the stratospheric column $\mathrm{O}_{3}$, the tropospheric ozone profile, and stratospheric ozone profile. However, Hudson et al. [1995] and Kim [1995] have shown that in the tropics the algorithm does not depend on the stratospheric ozone profile. The following procedures have been used to derive corrected total $\mathrm{O}_{3}$, timeaveraged stratospheric column $\mathrm{O}_{3}$, and tropospheric column $\mathrm{O}_{3}$ using measured tropospheric $\mathrm{O}_{3}$ profiles.

\subsection{Derivation of Total $\mathrm{O}_{3}, \Omega_{\text {tot }}$ From TOMS Radiances}

The current TOMS algorithm in the tropics uses a series of lookup tables based on standard profiles of 225,275 , and 325 DU. The amount assumed to be in the tropospheric is approximately $10 \%$ of the total amount, thus implying a coupling of stratospheric and tropospheric ozone. Table 1 shows climatological tropospheric column $\mathrm{O}_{3}$ for tropical and subtropical sites, including seven that were operational during SAFARI and TRACE A [Baldy et al., this issue; Kirchhoff et al., this issue; Thompson et al., this issue $(\mathrm{a}, \mathrm{b})]$. For non-SAFARI and TRACE A sites, September to November means are $26 \mathrm{DU}$ at Hilo $\left(19^{\circ} \mathrm{N}, 155^{\circ} \mathrm{W}\right)$ and Samoa $\left(14^{\circ} \mathrm{S}, 170^{\circ} \mathrm{W}\right)$ and $24 \mathrm{DU}$ at Manaus $\left(3^{\circ} \mathrm{S}, 60^{\circ} \mathrm{W}\right)$ [Komhyr et al., 1989; Watson et al., 1991]. Note that these values are similar to the minima observed during SAFARI/TRACE A at sites that recorded clean background soundings: Brazzaville, Cuiabá, and Okaukuejo. Values of $\sim 20-30$ DU are also typical for the tropical South Atlantic basin sites during the non-biomass burning season (Table 1). Weller et al. [1996] show mid-Atlantic ozone profiles 
(a)
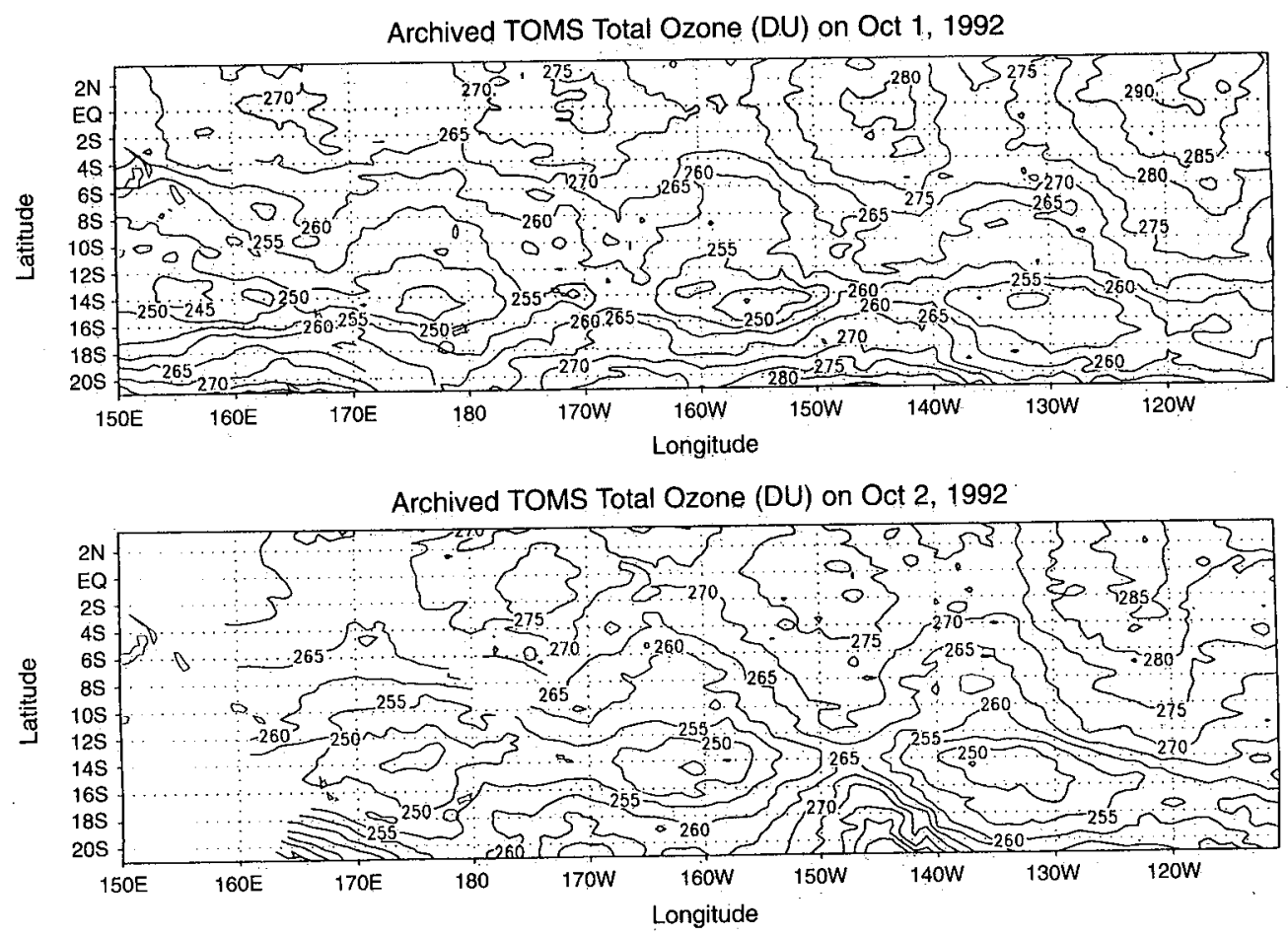

(b)

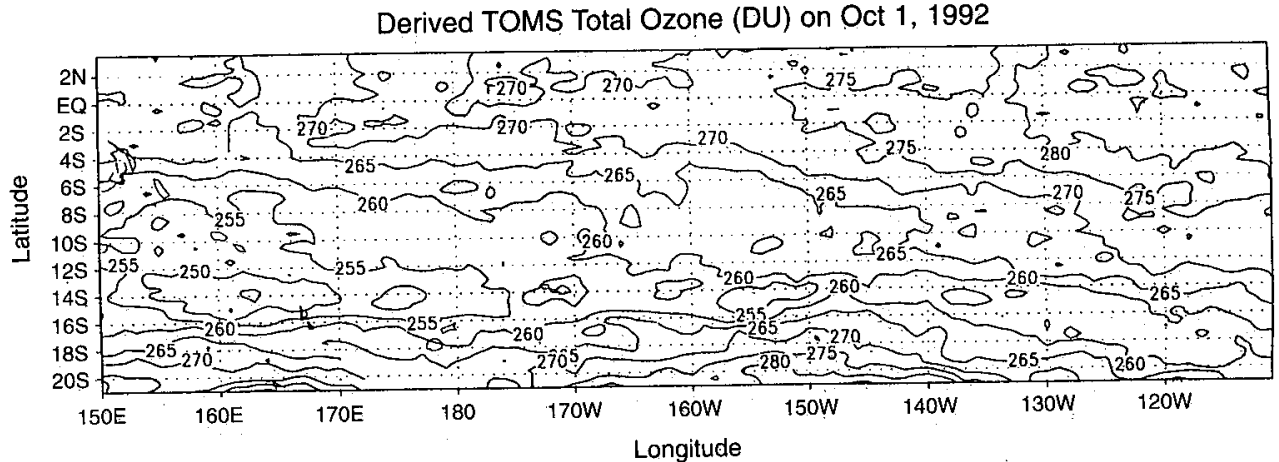

Derived TOMS Total Ozone (DU) on Oct 2, 1992

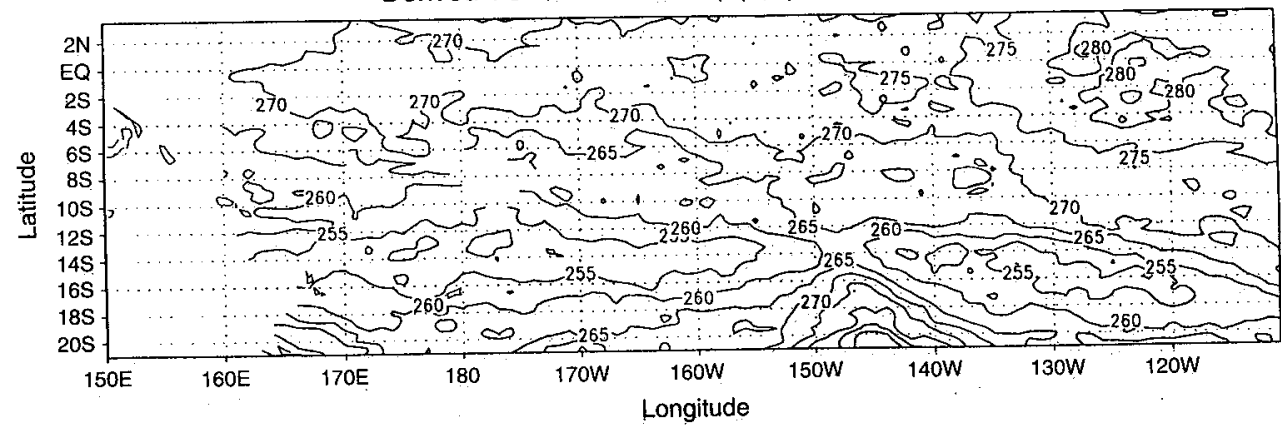

Figure 1. (a) Archived total $\mathrm{O}_{3}$ for the tropics from high-density TOMS tape, October 1 and 2, 1992. (b) Total $\mathrm{O}_{3}$ after correction for error due to a scan bias. Five DU intervals shown. This Pacific region was selected because tropospheric ozone is a minimum and it introduces no scan angle artifact into total ozone. Thus features due to attitude and Mt. Pinatubo aerosol effects are most pronounced.

from shipboard launches during October and November 1993. Background tropospheric ozone column $\left(0^{\circ}-10^{\circ} \mathrm{N}\right.$, tropopause at $16-17 \mathrm{~km}$ ) is $27 \mathrm{DU}$. In general, the SAFARI/TRACE A sondes show no evidence that tropospheric and stratospheric total ozone amounts are consistently coupled, in agreement with the shipboard record [Weller et al., 1996].
In order to obtain total ozone amounts from the measured radiances we have followed the same lookup table procedure as used in the TOMS algorithm, but new tables were generated from a set of profiles with varying stratospheric total ozone amounts and a fixed tropospheric column $\mathrm{O}_{3}$ of $26 \mathrm{DU}$. $\mathrm{A}$ description of the algorithm is given by Hudson et al. [1995] 


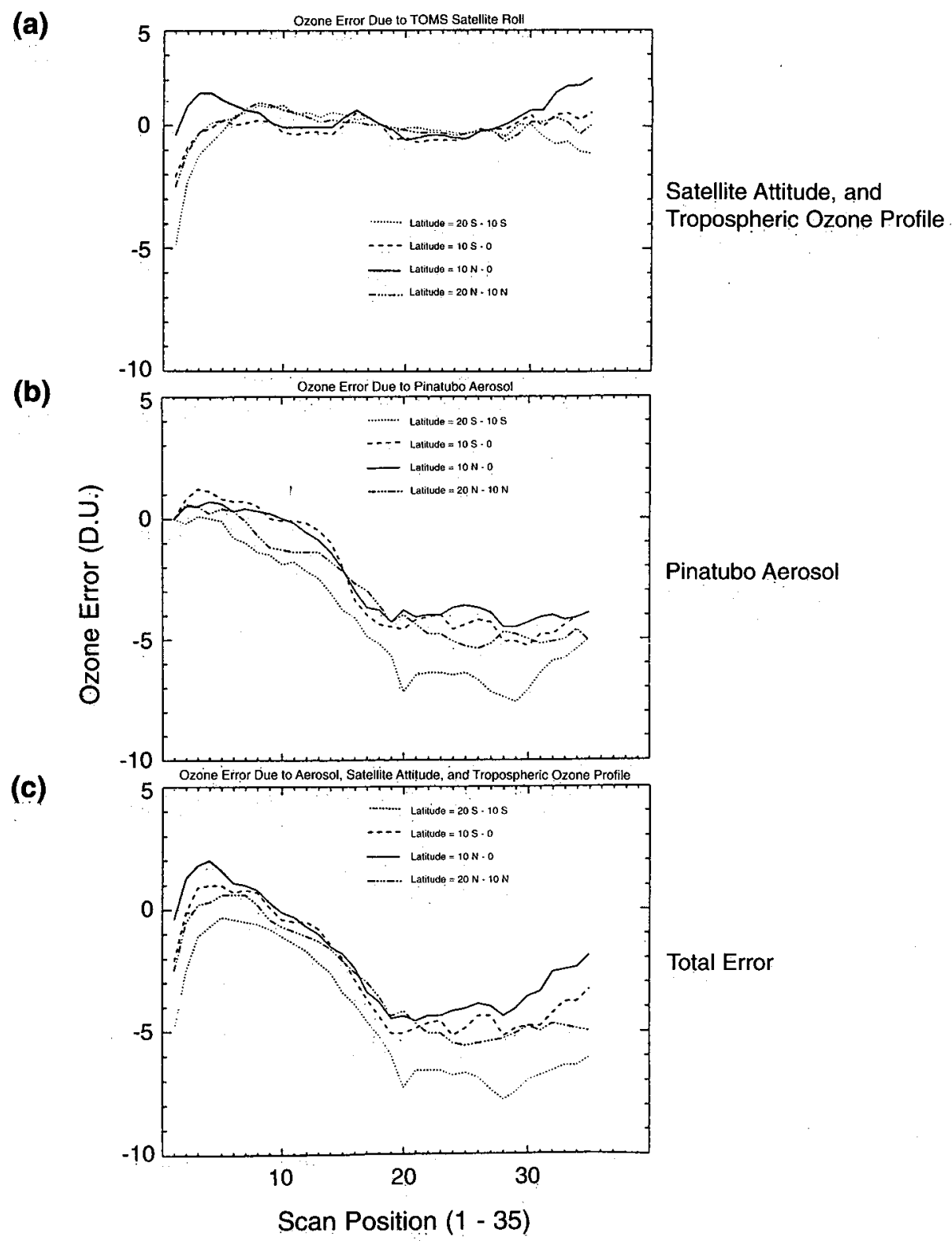

Figure 2. Ozone error due to (a) the error in scan angle and (b) Mt. Pinatubo aerosols. (c) Total error due to the error in scan angle and Mt. Pinatubo aerosols.

Since the retrieval efficiency for tropospheric $\mathrm{O}_{3}$ is less than that for stratospheric $\mathrm{O}_{3}[\mathrm{Hudson}$ et al., 1995], the algorithm underestimates the total $\mathrm{O}_{3}$ when the actual tropospheric column $\mathrm{O}_{3}$ is greater than that assumed in the tables. The correction for this underestimation is discussed in section 3.2. The derived total $\mathrm{O}_{3}$ over cloud-free regions based on the 26-DU tropospheric $\mathrm{O}_{3}$ assumption, and averaged over $2^{\circ}$ longitude and $1^{\circ}$ latitude bands for 16 days in October 1992, is shown in Plate 1.

\subsection{Derivation of Time-Averaged Stratospheric and Tropospheric $\mathrm{O}_{3}$}

Figure 3a shows the longitudinal variations of total $\mathrm{O}_{3}$ for the latitude band from $2^{\circ} \mathrm{S}$ to $2^{\circ} \mathrm{N}$. Figure $3 \mathrm{~b}$ shows a plot of the longitudinal variation for latitude bands at $14^{\circ} \mathrm{S}, 8^{\circ} \mathrm{S}$, and $10^{\circ} \mathrm{N}$, normalized to that shown in Figure $3 \mathrm{a}$. The longitudinal variation of total $\mathrm{O}_{3}$ at the equator is selected because the variation of stratospheric ozone with longitude has been measured to be smooth at the equator [Fishman et al., 1990] and is representative of the variation in other latitude bands. The areas from $180^{\circ} \mathrm{W}$ to $90^{\circ} \mathrm{W}$ (over the Pacific) and from $50^{\circ} \mathrm{E}$ to $100^{\circ} \mathrm{E}$ (over the Indian) are selected for this normalization procedure because they are least affected by anthropogenic activity [Fishman and Larsen, 1987; Fishman et al., 1990; Komhyr et al., 1989]. Note that the shapes of the total $\mathrm{O}_{3}$ fields track each other in the latitude bands from $14^{\circ} \mathrm{S}$ to $10^{\circ} \mathrm{N}$, except from Africa to South America. The composite plot shown in Figure 3 b shows a wavelike feature, which is observed in all the latitude bands, underlying sharp peaks which occur at different longitudes depending on the latitude. The wave feature is quite distinct from $10^{\circ} \mathrm{N}$ to $14^{\circ} \mathrm{S}$. Beyond these latitudes the wave shows a more complicated structure.

We have performed a similar analysis for the first half of each month during 1992 [Hudson et al., 1996] and for early October 1989. In the first case, all months in 1992 show a wave 
Table 1. Climatological Integrated Tropospheric Ozone for Non-Burning Season (March-April-May) and Minimum Value During SAFARI/TRACE A for South Atlantic, Brazil, African, and Indian Ocean Stations

\begin{tabular}{llcc}
\hline \multicolumn{1}{c}{ Station } & \multicolumn{1}{c}{ Location } & $\begin{array}{c}\text { March-April-May } \\
\text { Mean, DU }\end{array}$ & $\begin{array}{r}\text { Sept.-Oct. 1992 } \\
\text { Minimum, DU }\end{array}$ \\
\hline Ascension Island & $\left(8^{\circ} \mathrm{S}, 15^{\circ} \mathrm{W}\right)$ & 31 & 37 \\
Brazzaville & $\left(4^{\circ} \mathrm{S}, 15^{\circ} \mathrm{E}\right)$ & 33 & 24 \\
Goiânia, Brazil & $\left(16^{\circ} \mathrm{S}, 49^{\circ} \mathrm{W}\right)$ & 22 & n/a \\
Natal, Brazil & $\left(5^{\circ} \mathrm{S}, 35^{\circ} \mathrm{W}\right)$ & 27 & 40 \\
Cuiabá, Brazil & $\left(155^{\circ} \mathrm{S}, 56^{\circ} \mathrm{W}\right)$ & $n / \mathrm{a}$ & 28 \\
Okaukuejo, Namibia & $\left(19^{\circ} \mathrm{S}, 16^{\circ} \mathrm{W}\right)$ & $n / \mathrm{a}$ & 23 \\
La Réunion & $\left(22^{\circ} \mathrm{S}, 56^{\circ} \mathrm{E}\right)$ & 28 & 30 \\
Irene, South Africa & $\left(26^{\circ} \mathrm{S}, 28^{\circ} \mathrm{E}\right)$ & 29 & $\mathrm{n} / \mathrm{a}$ \\
Tutuila, American & $\left(14^{\circ} \mathrm{S}, 170^{\circ} \mathrm{W}\right)$ & 21 & $\mathrm{n} / \mathrm{a}$ \\
$\quad$ Samoa & $\left(20^{\circ} \mathrm{S}, 155^{\circ} \mathrm{W}\right)$ & 41 & \\
Hilo, Hawaii & & &
\end{tabular}

Ozone is in Dobson units to $16 \mathrm{~km}$.

structure similar to Figures $3 \mathrm{a}$ and $3 \mathrm{~b}$, from $4^{\circ} \mathrm{N}$ to $5^{\circ} \mathrm{S}$; beyond this band the definition of wavelike structures depends on the extent of the intrusion of midlatitude waves into the tropics. For October 1989 the wave structure is also strongly evident (Figure 3c), despite the fact that total ozone in the $10^{\circ} \mathrm{N}$-to$14^{\circ} \mathrm{S}$ band is $4 \mathrm{DU}$ less than its October 1992 counterpart.

For nearly all latitude bands shown in Figures $3 \mathrm{~b}$ and $3 \mathrm{c}$ elevated total ozone occurs between $60^{\circ} \mathrm{W}$ and $40^{\circ} \mathrm{E}$. North of the equator these correspond to regions of biogenic and industrial emissions conducive to ozone formation. The ozone precursor source strengths are not known, but if the enhancement above the normalized background is entirely due to tropospheric ozone, the amounts seem high. (We have not been able to obtain in situ ozone data north of the equator for any of the periods studied, but we derive tropospheric ozone columns in excellent agreement with sondes south of the equator). Upper tropospheric ozone formation, perhaps lightningNO-induced, is an alternative explanation. For October 1992, forward trajectories corresponding to altitudes of convective tower outflow $(9-12 \mathrm{~km})$, could carry air masses elevated in ozone or ozone precursors from Africa toward the Gulf of Guinea [Thompson et al., this issue (a)]. South of the equator, aircraft sampling on TRACE A showed that elevated ozone and ozone precursors were abundant over Africa and the eastern and central Atlantic [Gregory et al., this issue; Browell et al., this issue].

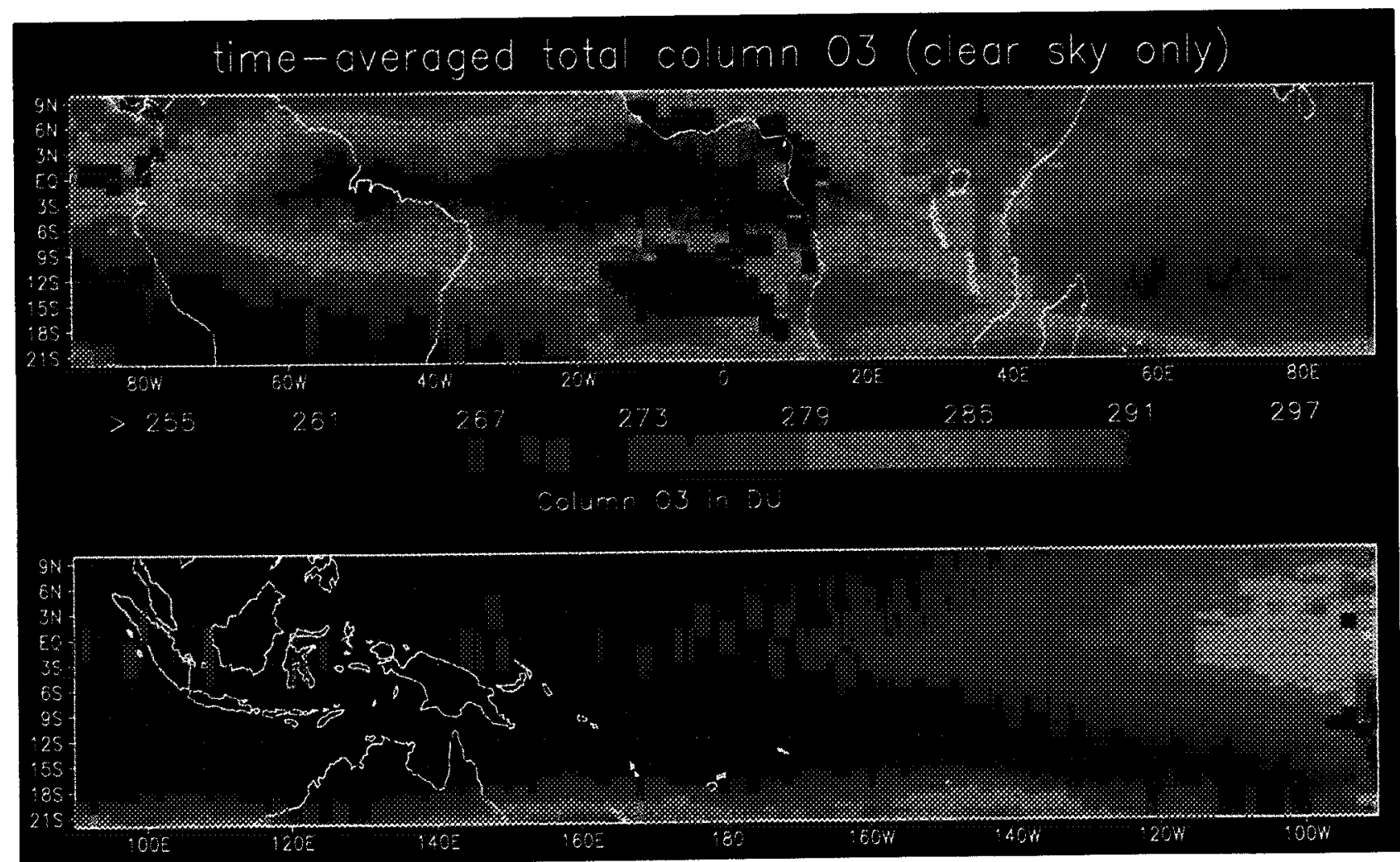

Plate 1. Derived time-averaged total column $\mathrm{O}_{3}$ over the tropics. Color bar represents column $\mathrm{O}_{3}$ in 5-DU intervals. 
(a)

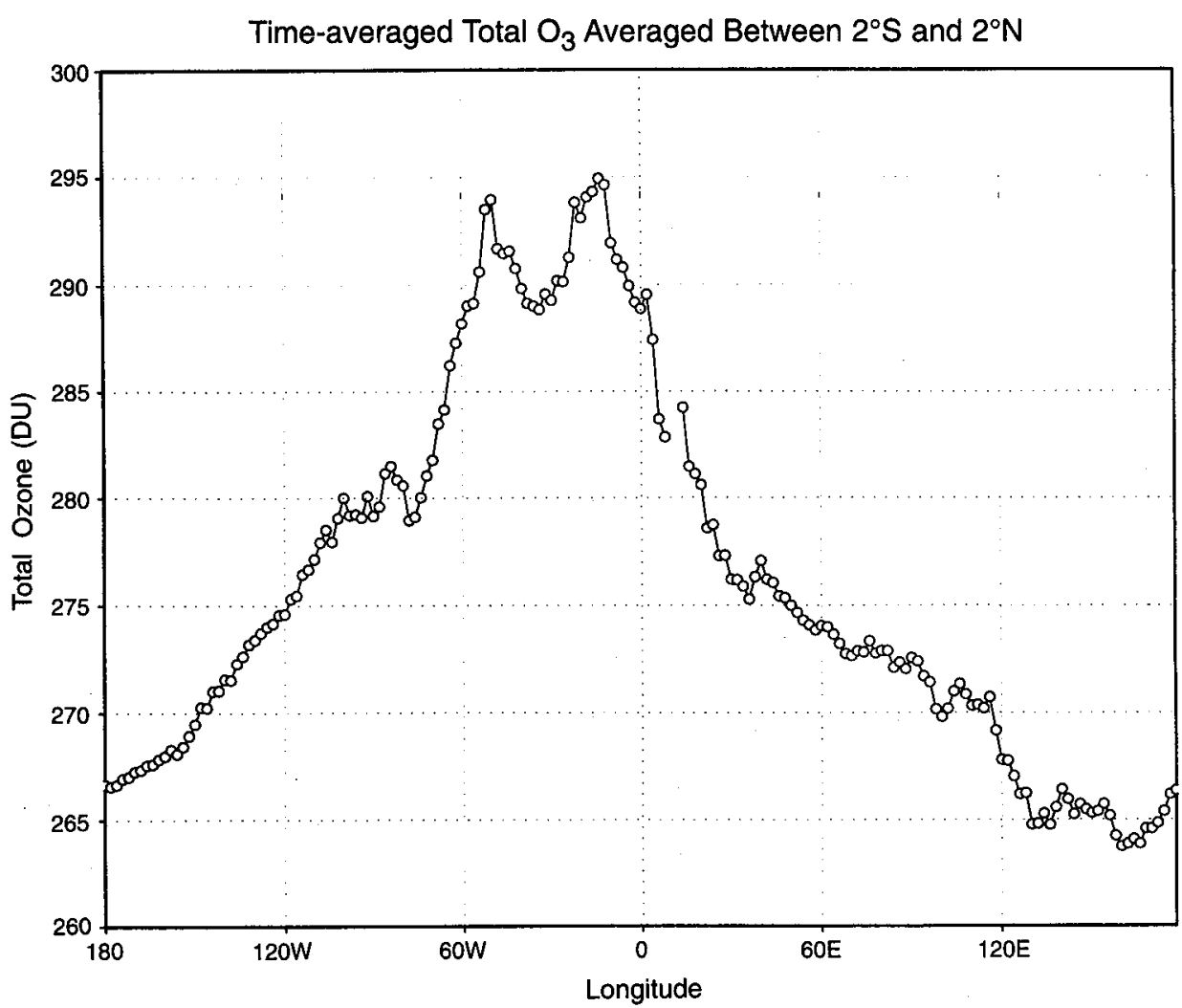

(b)

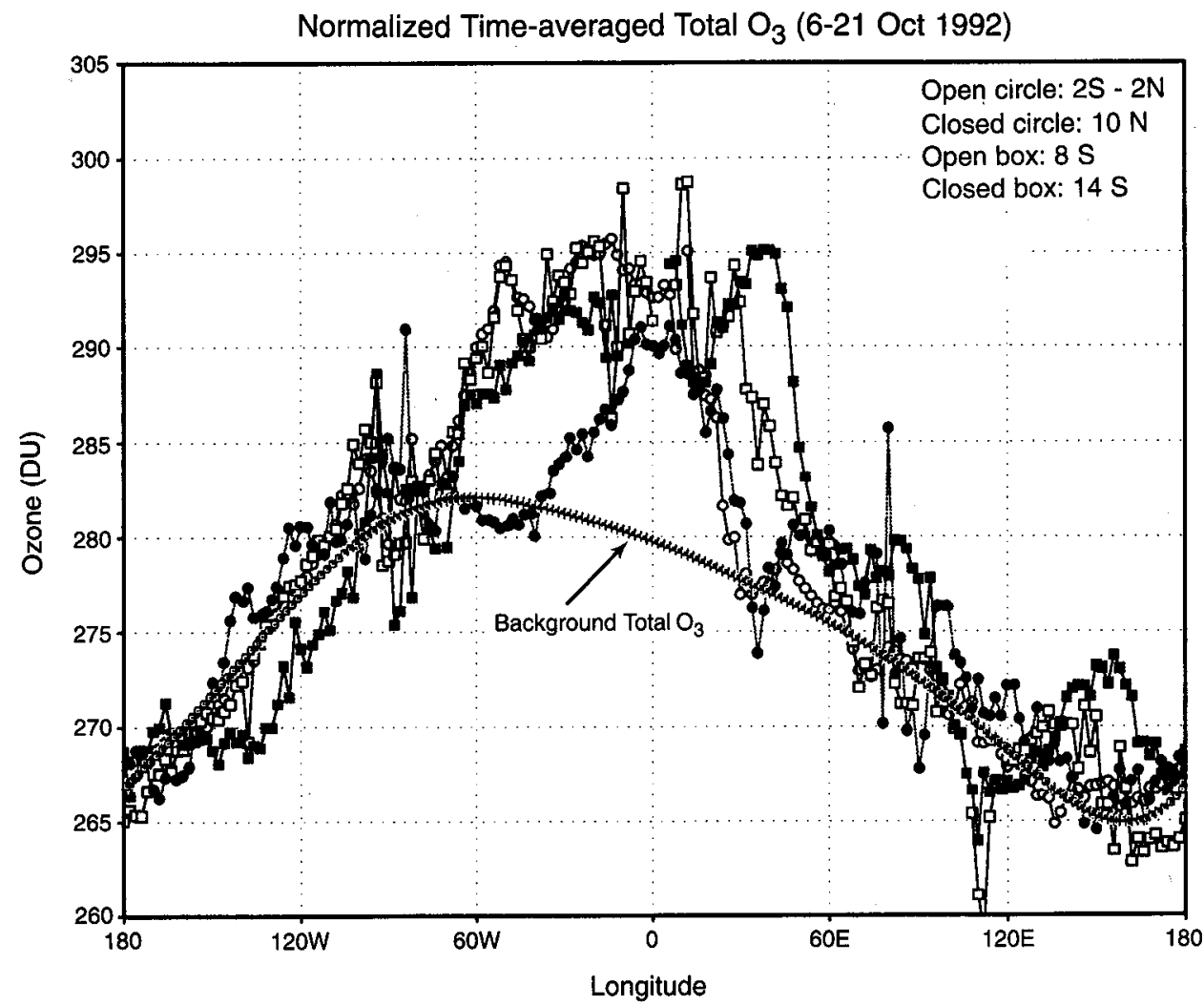

Figure 3. (a) Time-averaged total $\mathrm{O}_{3}$ averaged over latitude bands from $2^{\circ} \mathrm{S}$ to $2^{\circ} \mathrm{N}$ for October $6-21,1992$. (b) Normalized time-averaged total $\mathrm{O}_{3}$ and background total $\mathrm{O}_{3}$ (solid line) over the tropics. Each grid point is averaged over $2^{\circ}$ longitude and $1^{\circ}$ latitude. (c) Normalized time-averaged ozone and background total $\mathrm{O}_{3}$ for October 6 21, 1989. 
(c)

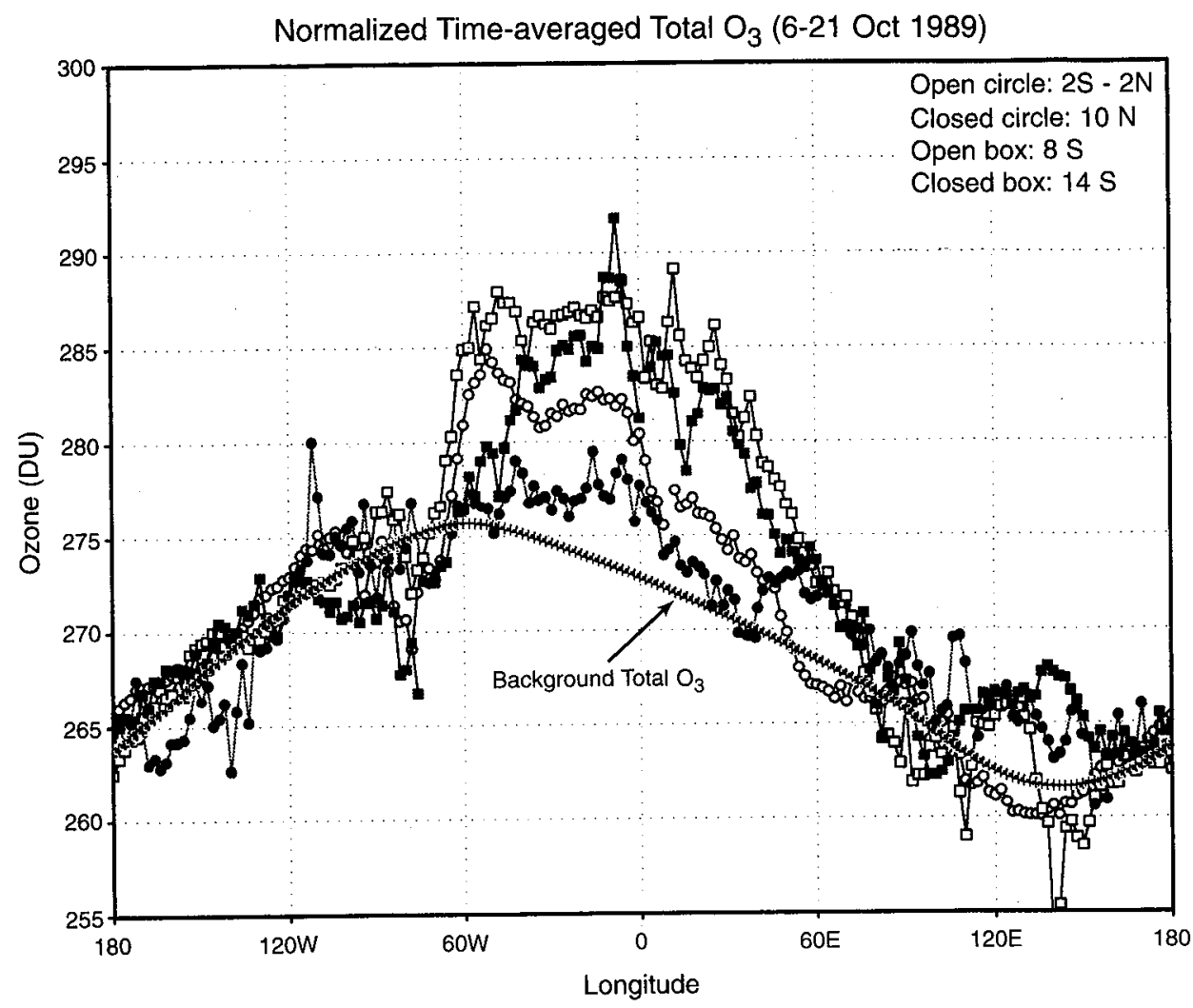

Figure 3. (continued)

The wave structure in Figure 3 suggests an approach to deriving tropospheric ozone. Consider that total ozone, $\Omega_{\text {tot }}$, consists of a highly variable amount above the normalization curve (Figure 3), plus the amount indicated by the latter, the background amount of ozone, $\Omega_{\mathrm{bck}}$. Then the difference between those two quantities, corrected with the retrieval efficiency for tropospheric ozone ( $\varepsilon$, less than unity for high concentrations of ozone below 500 mbar), is

$$
\Omega_{\mathrm{tr}}=\left[\Omega_{\mathrm{tot}}-\Omega_{\mathrm{bck}}\right] / \varepsilon+\Omega_{\mathrm{tr}, \mathrm{bck}}
$$

where $\Omega_{\mathrm{tr} \text {, bck }}$ is a background amount of tropospheric ozone. All quantities are in Dobson units. Now what is $\Omega_{\text {tr, bck }}$ ? The minimum amount, as indicated above from the soundings, is 26 DU independent of longitude. In that case the wave structure is assumed to be in the stratosphere and $\Omega_{\text {bck }}=\Omega_{\text {strat }}+26$ $\mathrm{DU} ; \Omega_{\mathrm{bck}}$ at a given latitude is actually a modified parameter, derived by renormalizing the originally derived $\Omega_{\mathrm{bck}}$ to the wave 1 curve in Figure 3b. This assumption leads to Plate 2 for the time-averaged tropospheric ozone field for October 6-21, 1992. Since the retrieval efficiency depends on the tropospheric $\mathrm{O}_{3}$ profile, we use averaged profiles derived from Ascension Island, Brazzaville, and Okaukuejo ozone soundings during September and October 1992 (Table 1). Calculated timeaveraged retrieval efficiency $(\varepsilon)$ is about 0.75 under clear sky conditions and about 1.0 over marine stratocumulus clouds in the tropics.

An alternative is to assume a longitudinally invariant stratospheric ozone amount, which is not very different from what SAGE usually shows, though SAGE was not available for late 1992 , owing to the Mt. Pinatubo eruption. This was the approach used by Hudson et al. [1995], and it effectively ascribes the wave structure in Figure 3 to tropospheric ozone. Because SAGE data were not available, we have assumed that the stratospheric ozone field can be obtained by subtracting $26 \mathrm{DU}$ from the total ozone near $180^{\circ}$ longitude. Thus (1) is still used to derive $\Omega_{\mathrm{tr}}$, but $\Omega_{\mathrm{bck}}=\Omega_{\mathrm{tr} \text {, bck }}$ plus a fixed amount assumed for $\Omega_{\text {strat }}$. Plate 3 shows the averaged tropospheric ozone field for October 6-21, 1992, with this assumption.

\subsection{Equatorial Wave Structure}

A number of studies have considered wave structures in equatorial $\mathrm{O}_{3}$ that are apparent when total ozone and the deviation from zonal mean total ozone are viewed as a function of longitude. A Kelvin wave [Andrews et al., 1987; Tsuda et al., 1994], with wave number 1 or 2 and with both 7-day and 15- to 20-day periods, has a 2- to 4-DU magnitude [Ziemke and Stanford, 1994]. Another contribution to total ozone is a mixed Rossby-gravity wave with wave number 4 , and a 4- to 5-day period, also of magnitude 2-4 DU [Stanford and Ziemke, 1993]. Shiotani and Hasebe [1994] found no evidence of a wave in SAGE ozone corresponding to that seen in TOMS and concluded that the wave must be primarily tropospheric. However, SAGE ozone profiles are $\geq 30 \%$ uncertain below 100 mbar, and a wave pattern would be difficult to isolate. Table 2 summarizes the SAGE-derived ozone thickness in 2-km layers in the upper troposphere-lower stratosphere, for all observations between $10^{\circ} \mathrm{N}$ and $10^{\circ} \mathrm{S}$ in $1989-1990$. The second column of Table 2 is ozone integrated from top of atmosphere down to the specified altitude.

Comparison of TOMS total ozone and stratospheric ozone from the microwave limb sounder (MLS) on UARS) also suggests a primarily tropospheric wave [Ziemke et al., 1996], al- 


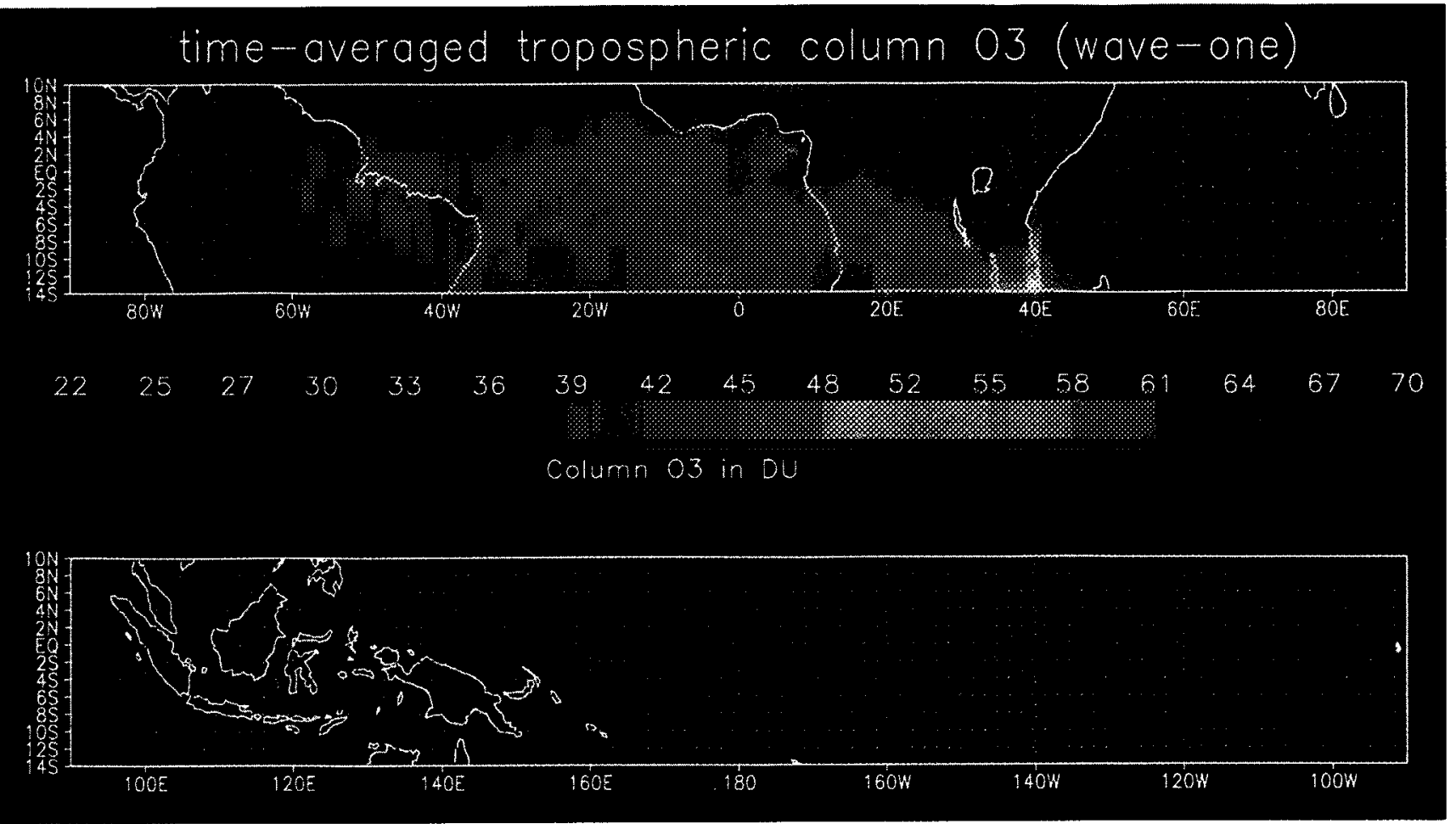

Plate 2. Derived time-averaged tropospheric column $\mathrm{O}_{3}$ over the tropics, assuming that the wavelike feature in Plate 1 is in the stratosphere. Color bar represents column $\mathrm{O}_{3}$ in 3-DU intervals.

though ozone is $\geq 40 \%$ uncertain below 68 mbar, (E. Fishbein, Jet Propulsion Laboratory, UARS Science Team documentation, 1994). A comparison of TRACE A Ascension sondes (September-October 1992) with a climatology of Samoa sondes (September-October for 1986-1989) implies that the wave is largely tropospheric, but no Pacific sondes were available for an actual differencing of Atlantic-Pacific ozone profiles in 1992. Preliminary analysis with version 7 TOMS ozone

time-averaged tropospheric column 03 (flat stratospheric 03)

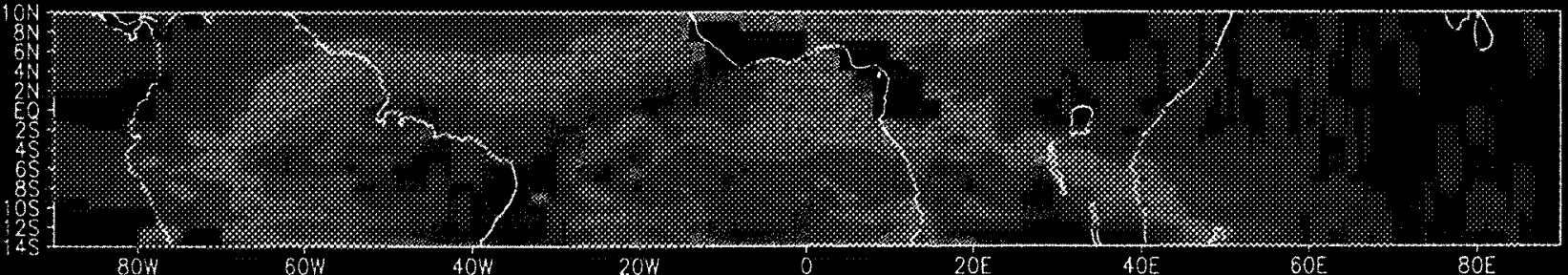

$\begin{array}{llllllllllllllll}22 & 25 & 27 & 30 & 33 & 36 & 39 & 42 & 45 & 48 & 52 & 55 & 58 & 61 & 64 & 67\end{array}$

Column 03 in Du

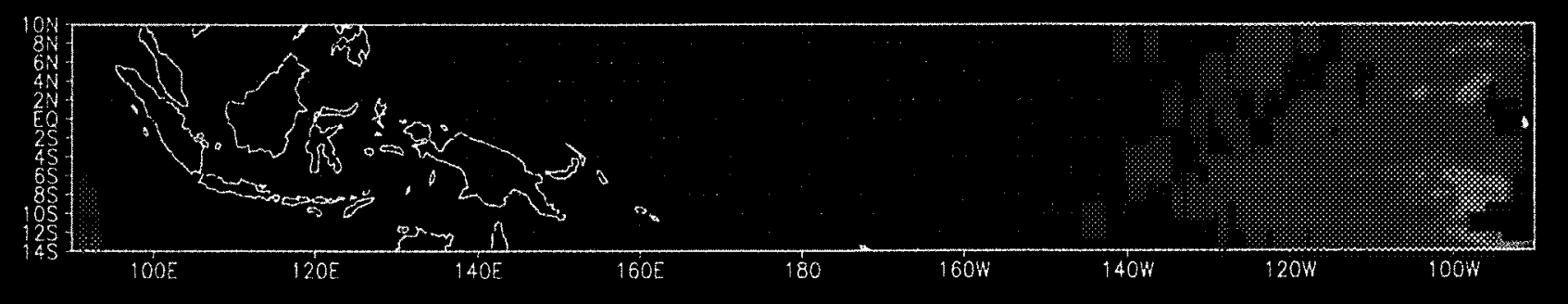

Plate 3. Same as Plate 2, except assuming a flat stratosphere, that is, a tropospheric wave. The latter is similar to a "residual method." Color bar represents column $\mathrm{O}_{3}$ in 3-DU intervals. 
including all months of 1992 shows that the wave pattern is present year-round (discussed by Ziemke et al. [1996] and C. N. Hsu et al., The effect of an improved cloud climatology on the TOMS total ozone retrieval, submitted to Journal of Geophysical Research, 1996] and that contributions of stratospheric and tropospheric ozone to the wave pattern vary from month to month [Hudson et al., 1996]. In section 5 it is shown that assuming a stratospheric wave gives better agreement with TRACE A sondes over Brazil, Ascension, and Africa in October 1992.

\section{Error Analysis of the New Method}

By far the largest source of error is in the choice of the stratospheric ozone field. If the wave 1 pattern is in the stratosphere, then an error arises from uncertainties in drawing the best-fit underlying pattern in Figure $3 b$. The shape of this curve is based largely on the longitudinal variation of total $\mathrm{O}_{3}$ at the equator. The magnitude of this error can be estimated from the standard deviation of the total $\mathrm{O}_{3}$ at a given latitude from the best-fit curve. The standard deviations, calculated from $180^{\circ} \mathrm{E}$ to $80^{\circ} \mathrm{W}$ and from $60^{\circ} \mathrm{E}$ to $100^{\circ} \mathrm{E}$, which are the regions with less anthropogenic activity, are less than 2 DU. This leads to an error in tropospheric $\mathrm{O}_{3}$ of $3 \mathrm{DU}$.

The second error arises from uncertainty in the retrieval efficiency. Hudson et al. [1995] suggested that this error is less than $2 \mathrm{DU}$ in derived tropospheric column $\mathrm{O}_{3}$ on a daily basis. This error occurs due to the difference between actual and assumed tropospheric $\mathrm{O}_{3}$ profile shape on a daily basis. Presumably, this error is less over the period of 15 days because we used averaged $\mathrm{O}_{3}$ profiles measured from ozone soundings during the same period as our case study.

The third error will occur where background tropospheric $\mathrm{O}_{3}$ differs from the assumed background $\mathrm{O}_{3}$ of $26 \mathrm{DU}$. The difference would propagate directly to an error in derived tropospheric $\mathrm{O}_{3}$. For example, if the actual background tropospheric $\mathrm{O}_{3}$ is $31 \mathrm{DU}$ instead of $26 \mathrm{DU}$, the derived tropospheric $\mathrm{O}_{3}$ will be underestimated by $5 / \varepsilon$, which are about 7 DU under clear sky and 5 DU under cloudy sky conditions, respectively. Looking at the minimum $\mathrm{O}_{3}$ values during $\mathrm{SA}$ FARI/TRACE A for Brazzaville, Cuiabá, and Okaukuejo (Table 1), it seems unlikely that this error could be larger than 5 DU. Indeed, we have tried to use a moderate value of "background" ozone to avoid exaggerating regional variations.

\section{Intercomparison of TOMS-Derived Tropospheric $\mathrm{O}_{3}$ With SAFARI/TRACE A Data}

Table 3 shows a comparison between total tropospheric ozone derived from the sonde measurements and that derived

Table 2. SAGE-Derived Ozone Thicknesses in 2-km Layers in the Upper Troposphere-Lower Stratosphere

\begin{tabular}{cccc}
\hline $\begin{array}{c}\text { Altitude, } \\
\mathrm{km}\end{array}$ & $\begin{array}{c}\text { Ozone Column } \\
\text { to Altitude, DU }\end{array}$ & $\begin{array}{c}\text { Incremental } \\
\text { Ozone, DU }\end{array}$ & $\begin{array}{c}1 \sigma \text { Uncertainty in } \\
\text { Incremental } \\
\text { Ozone, DU }\end{array}$ \\
\hline 19 & $230.35(619)$ & $\ldots$ & $\ldots$ \\
17 & $236.73(617)$ & 15.4 & 2.63 \\
15 & $241.94(581)$ & 6.39 & 2.43 \\
13 & $244.90(411)$ & 2.96 & 7.20 \\
\hline
\end{tabular}

Thicknesses are for all observations between $1^{\circ} \mathrm{N}$ and $1^{\circ} \mathrm{S}$ in $1989-$ 1990. The second column is ozone integrated from top of atmosphere down to the specified altitude. Numbers in parentheses are numbers of observations. DU, Dobson unit.
Table 3. Sonde and TOMS-Derived Tropospheric Ozone From October 6 to 21, 1992

\begin{tabular}{|c|c|c|c|}
\hline \multirow[b]{2}{*}{ Location (latitude, longitude) } & \multicolumn{3}{|c|}{ Ozone, DU } \\
\hline & $\begin{array}{l}\text { Sonde- } \\
\text { Derived }\end{array}$ & $\begin{array}{l}\text { TOMS- } \\
\text { Derived } \\
\text { (Plate 2) }\end{array}$ & $\begin{array}{l}\text { TOMS- } \\
\text { Derived } \\
\text { (Plate 3) }\end{array}$ \\
\hline Brazzaville $\left(40^{\circ} \mathrm{S}, 150^{\circ} \mathrm{E}\right)$ & $40(7)$ & 38 & 57 \\
\hline Ascension Island $\left(8^{\circ} \mathrm{S}, 15^{\circ} \mathrm{W}\right)$ & $52(6)$ & 48 & 58 \\
\hline Natal $\left(5^{\circ} \mathrm{S}, 35^{\circ} \mathrm{W}\right)$ & $48(4)$ & 46 & 62 \\
\hline Cuiabá $\left(15.5^{\circ} \mathrm{S}, 56^{\circ} \mathrm{W}\right)$ & $41(3)$ & $40^{*}$ & $50^{*}$ \\
\hline Samoa $\left(14^{\circ} \mathrm{S}, 170^{\circ} \mathrm{W}\right)$ & 26 (climatology) & 25 & 28 \\
\hline
\end{tabular}

"Plate 2 " refers to identifying the wave as stratospheric; "plate 3 " refers to identifying the wave as tropospheric. Numbers in parentheses indicate the number of ozonesonde measurements.

*Comparisons from southern limit of Plates 2 and $3: 14^{\circ} \mathrm{S}, 56^{\circ} \mathrm{W}$.

from the new method for the two different assumptions about the nature of the wave 1 pattern. The number in the parenthesis in the second column is the number of ozonesonde measurements for the period October 6-21, 1992. Since derivation of ozone from this method is limited to $14^{\circ} \mathrm{S}-10^{\circ} \mathrm{N}$, the ozone value at $14^{\circ} \mathrm{S}, 56^{\circ} \mathrm{W}$ is given for comparison with Cuiabá, Brazil. The value at Samoa is the climatological tropospheric ozone from September to October [Komhyr et al., 1989]. Best agreement between the tropospheric ozone derived from the new method and the sondes is for the assumption that the wave one pattern is in the stratosphere.

Figure 4 shows a composite of integrated tropospheric column ozone taken by the Langley uv-DIAL instrument on board the NASA DC-8 during the TRACE A aircraft mission in October 1992 [Browell et al., this issue]. The uv-DIAL measured ozone profiles above and below the DC- 8 simultaneously, and the integrated column amount was obtained by combining above- and below-aircraft ozone amounts. Flights 13-18 were west of Africa over the Atlantic, with flights 13-15 originating and returning to Windhoek, Namibia, between Oc-

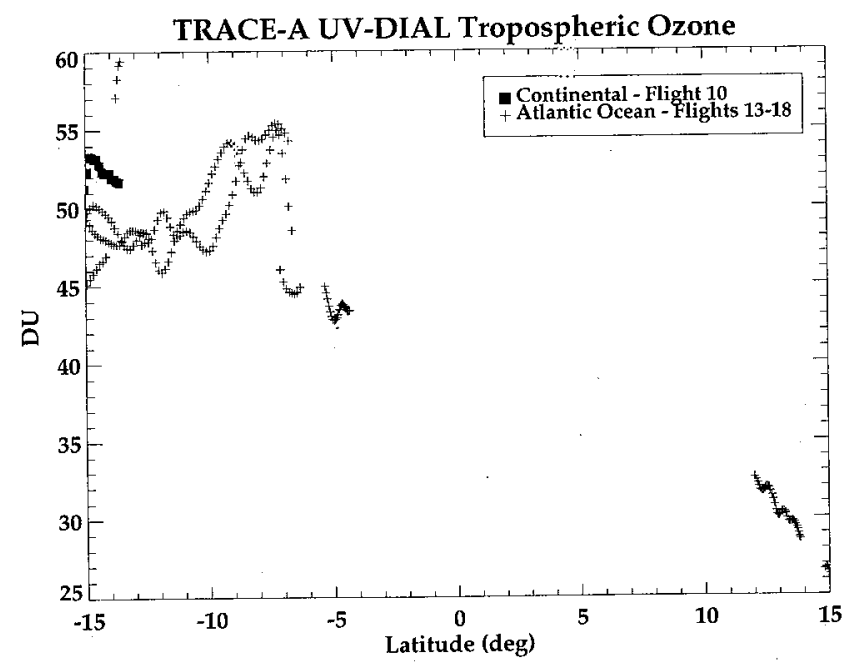

Figure 4. Uv-DIAL integrated tropospheric ozone from flights over southern Africa and the tropical Atlantic; flights occurred from October 6 to 22, 1992. Flight tracks are given by Fishman et al. [this issue (a)]. Longitudinal range of data displayed is $20^{\circ} \mathrm{W}$ to $30^{\circ} \mathrm{E}$. Sun angle prevented collection of data between $4^{\circ} \mathrm{S}$ and $10^{\circ} \mathrm{N}$ [from Browell et al., this issue]. 
Table 4. Area-Averaged Tropospheric $\mathrm{O}_{3}$ and Budget Over the Tropics

\begin{tabular}{llcc}
\hline & & \multicolumn{2}{c}{$\begin{array}{c}\text { Tropospheric } \mathrm{O}_{3} \\
\text { Column }\end{array}$} \\
\cline { 3 - 4 } \multicolumn{1}{c}{ Location } & Longitude, Latitude & $\Sigma, \mathrm{DU}$ & Budget, $\mathrm{Tg}^{*}$ \\
\hline South America & $75^{\circ}-40^{\circ} \mathrm{W}, 0^{\circ}-14^{\circ} \mathrm{S}$ & 39 & 1.6 \\
Atlantic & $40^{\circ} \mathrm{W}-12^{\circ} \mathrm{E}, 0^{\circ}-14^{\circ} \mathrm{S}$ & 45 & 3.5 \\
Southern Africa & $12^{\circ}-50^{\circ} \mathrm{E}, 0^{\circ}-14^{\circ} \mathrm{S}$ & 37 & 1.5 \\
Area 1 & $12^{\circ}-50^{\circ} \mathrm{E}, 0^{\circ}-5^{\circ} \mathrm{S}$ & 31 & 0.3 \\
Area 2 & $12^{\circ}-50^{\circ} \mathrm{E}, 5^{\circ}-10^{\circ} \mathrm{S}$ & 38 & 0.6 \\
Area 3 & $12^{\circ}-50^{\circ} \mathrm{E}, 10^{\circ}-14^{\circ} \mathrm{S}$ & 44 & 0.6
\end{tabular}

Areas within indicated latitude-longitude ranges: South America, $6.1 \times 10^{6} \mathrm{~km}^{2}$; Atlantic, $9.0 \times 10^{6} \mathrm{~km}^{2}$; Africa, $6.6 \times 10^{6} \mathrm{~km}^{2}$.

${ }^{*} 1 \mathrm{tg}$ is equal to $1 \times 10^{12} \mathrm{~g}$.

tober 14 and 18, 1992. Flight tracks are given by Fishman et al. [this issue (a)]; the longitudinal range of the data displayed in Figure 4 is $20^{\circ} \mathrm{W}$ to $30^{\circ} \mathrm{E}$. The mean between $4^{\circ} \mathrm{S}$ and $15^{\circ} \mathrm{S}$ is 50 DU, in good agreement with the 45-DU amount from the TOMS-derived tropospheric ozone method (Table 4). On the one continental flight (Flight 10, October 6, 1992) that reached to biomass burning regions of Africa (northern Zambia, $10^{\circ} \mathrm{S}$ $30^{\circ} \mathrm{E}$ ), column integrated ozone was $51-53$ DU. This is just within the range of our map in Plate 2, where the ozone column is 51-54 DU. The map shown in Plate 3 does not agree with the uv-DIAL results. Values of 50-55 DU over the eastern Pacific and about 70 DU over south-central Africa in Plate 3 are too high. The TOMS/solar backscattered ultraviolet (SBUV) method [Fishman et al., this issue (b)] of deriving tropospheric ozone also does not reproduce the northern Zambian $\mathrm{O}_{3}$ maximum seen in the uv-DIAL.

In summary, both the sondes and the uv-DIAL measurements support the tropospheric ozone map given in Plate 2. The remainder of our analysis is based on these data.

\section{Analysis of Derived Tropospheric Column Ozone}

The overall features from Plate 2 are (1) very high ozone from South America to Africa, (2) relatively low ozone off the western coast of South America and from the Indian to the west Pacific Ocean, (3) relatively enhanced ozone over northern Australia and New Guinea, and (4) a plumelike structure extending from the eastern Pacific to central Pacific. We discuss the Atlantic and Pacific panels of Plate 2 separately.

\subsection{Tropospheric $\mathrm{O}_{3}$ From Eastern South America Through Africa}

Tropospheric $\mathrm{O}_{3}$ of about $40 \mathrm{DU}$ is observed over northwest central Africa near the Intertropical Convergence Zone (ITCZ), (equator to $10^{\circ} \mathrm{N}$ ). The source of elevated tropospheric $\mathrm{O}_{3}$ over this region is uncertain. Because the biomass burning season in northern Africa is from December to February [Marenco et al., 1990; Cros et al., 1991], local burning over the savanna $\left(8^{\circ} \mathrm{N}\right.$ to $\left.15^{\circ} \mathrm{N}\right)$ is probably not the cause of enhanced tropospheric $\mathrm{O}_{3}$. Biogenic sources of ozone precursors (e.g., hydrocarbons, $\mathrm{CO}$, and $\mathrm{NO}$ ) [Zepp et al., this issue; Harris et al., this issue] from the rain forest $\left(8^{\circ} \mathrm{N}\right.$ to $3^{\circ} \mathrm{S}$ and $15^{\circ} \mathrm{W}$ to $30^{\circ} \mathrm{E}$ ) could contribute 2 - to 3-DU boundary layer ozone. Ozone from lightning NO near the ITCZ and/or ozone formed following convective outflow was observed during TRACE A
Brazilian sampling [Pickering et al., this issue]. In general, $\mathrm{Ol}$ son et al. [this issue] and Thompson et al. [this issue (a), 1996] note that in September and October 1992, the highest tropospheric ozone recorded at Natal and Ascension occurred when upper level westerlies transport air masses from convectively active regions during the latter part of the South American biomass burning season. However, back trajectories run with the Goddard isentropic trajectory model from -300 and 700 mbar show that the $\mathrm{O}_{3}$ feature of $50 \mathrm{DU}$ near $3^{\circ} \mathrm{N}, 8^{\circ} \mathrm{W}$ originates from northwest central Africa. There is no trace gas data available for this region, but industrial pollution could be present [Sieber et al., 1995; Thompson et al., 1996, this issue (a)]. Northeast central Africa, in contrast, is under the influence of clean air transported from the Indian Ocean (see mean winds in Figure 5) and does not reflect significant burning input because most African savanna burning during October 1992 occurs between $10^{\circ}$ and $20^{\circ} \mathrm{S}$ [Justice et al., this issue].

Figure 6 shows southern African fire counts for October $1-15,1992$, in southern Africa. Southeast central Africa is close to the intensive northern Zambian burning region, with a tropospheric $\mathrm{O}_{3}$ column up to $60 \mathrm{DU}$. This suggests that $\mathrm{O}_{3}$ is rapidly formed from fresh precursors in the burning regions. Model calculations using SAFARI and TRACE A aircraft measurements of $\mathrm{O}_{3}$ and $\mathrm{O}_{3}$ precursors ( $\mathrm{CO}, \mathrm{NO}$, nonmethane hydrocarbons) in the lower troposphere near active burning show that a typical cross section of air influenced by biomass burning (from boundary layer to tropopause) produces 10-15 ppbv $\mathrm{O}_{3} /$ day ( $\sim 5 \mathrm{DU}$ column integrated). Furthermore, except in the boundary layer, the $\mathrm{O}_{3}$ photochemical lifetime is several weeks. This lifetime, coupled with lifetimes of stable, recirculating layers of or greater than 1 week, over southern Africa [Garstang et al., this issue; Tyson et al., 1996] causes ozone to accumulate in this region. The persistent anticyclone that causes this recirculation means that south of $18^{\circ} \mathrm{S}$, only $4 \%$ of air masses exits Africa toward the Atlantic Ocean [Garstang et al., this issue].

In the upper troposphere over Africa and the Atlantic, TRACE A measurements suggest that there is net $\mathrm{O}_{3}$ production rate at $1-5 \mathrm{ppbv}_{3} /$ day. This corresponds to tropospheric $\mathrm{O}_{3}$ column production of 1-2 DU/day, a feature that shows up in time versus longitude (Hovmöller) plots of TOMS total $\mathrm{O}_{3}$ [Thompson et al., this issue (b), 1996]. Thus a high tropospheric $\mathrm{O}_{3}$ column over the eastern Atlantic reflects transport of lowlevel to midlevel ozone from Africa, supplemented by a steady rate of upper tropospheric ozone formation during transit from both continents. This is seen in the high south Atlantic ozone shown in Plate 2 and the wind fields shown in Figure 5.

Biomass burning-linked $\mathrm{O}_{3}$ coincident with middle tropospheric flows from both South America and Africa [Andreae et $a l ., 1994 \mathrm{~b}]$ were also observed on western Atlantic flights during Chemical Instruments and Test Evaluation-3 (1989). Thompson et al. [this issue (a)] posed the following question: How much of the tropospheric ozone above background level ("excess ozone") over the south Atlantic basin during SAFARI/ TRACE A was due to African origins and how much was due to South American origins? By running back trajectories from ozone-enriched layers observed on every Natal, Ascension, and Brazzaville sounding, it was determined that $20-25 \%$ of excess ozone at Natal and Ascension was from South America, with $70-75 \%$ from Africa. Up to $10 \%$ of the excess had recirculated so long over the Atlantic that the ultimate continental origin was indeterminate. All the Brazzaville soundings corresponded to African origins. 
(a)

\section{$850 \mathrm{mb}$ Wind Fields}

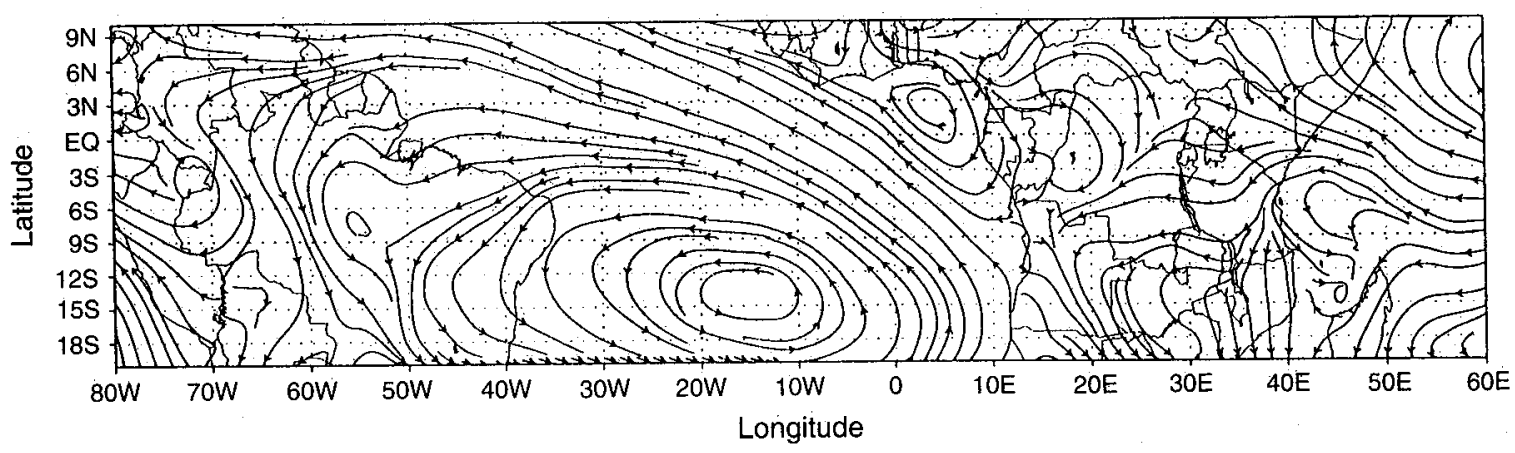

(b)

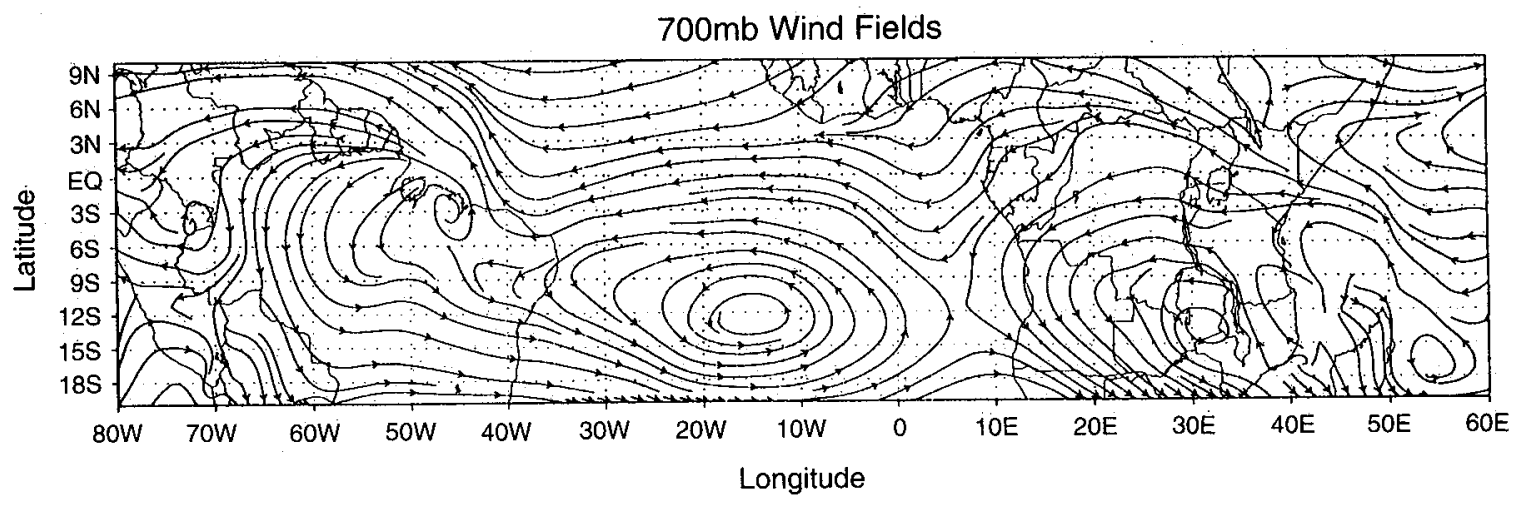

(c)

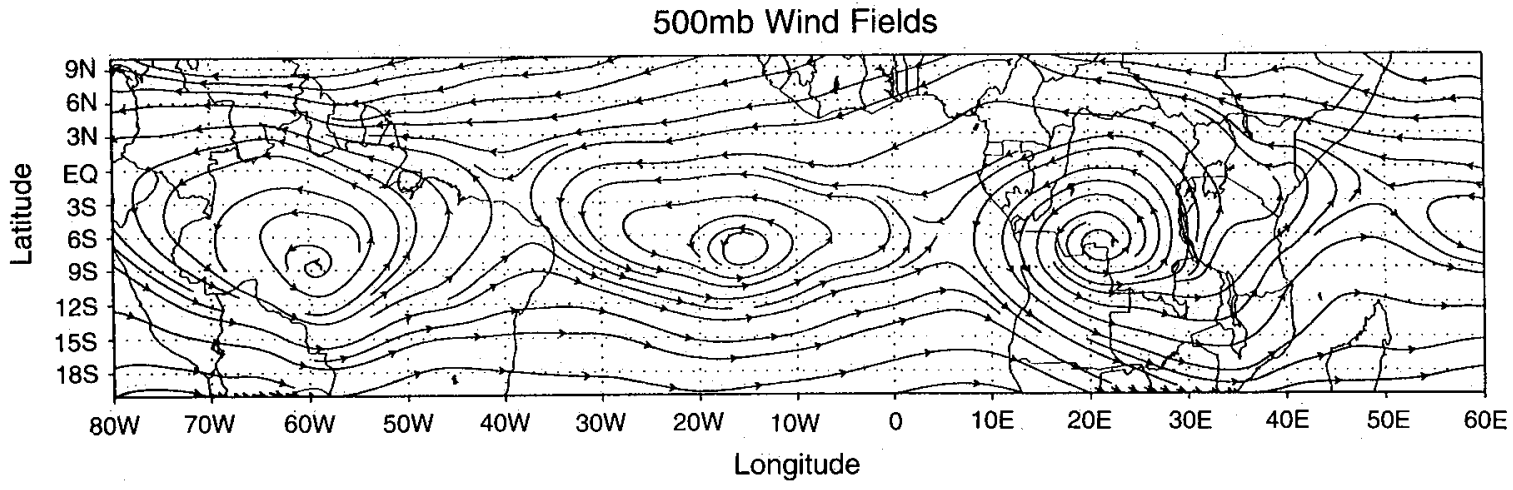

(d)

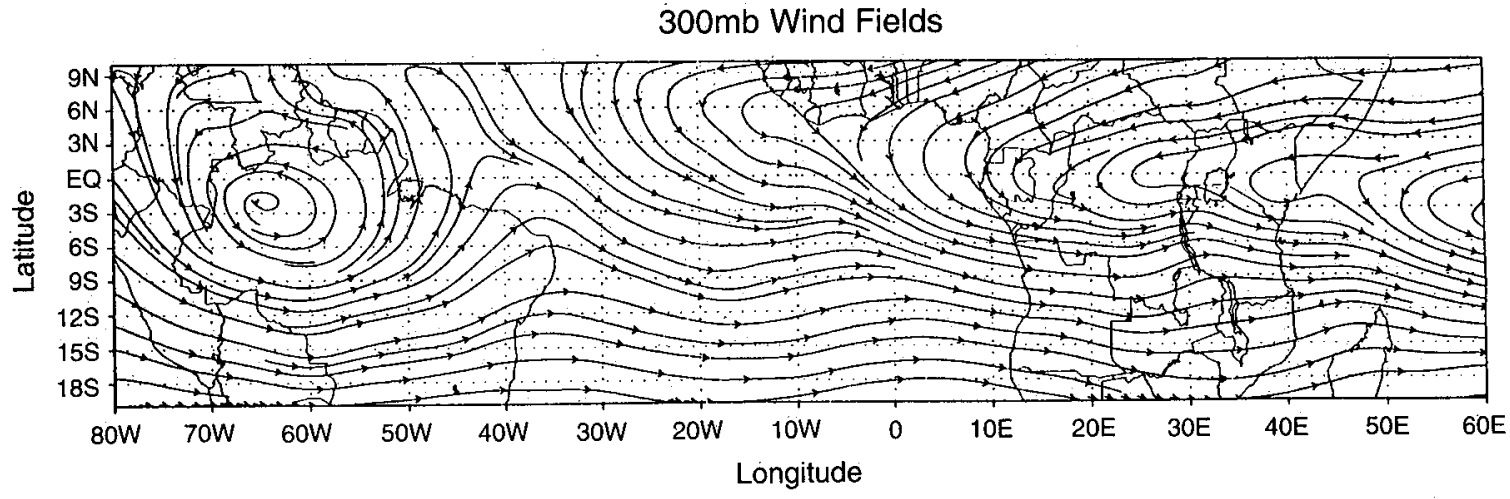

Figure 5. Time-averaged streamlines at (a) 850, (b) 700, (c) 500, and (d) 300 mbar from October 6 to 22, 1992. 


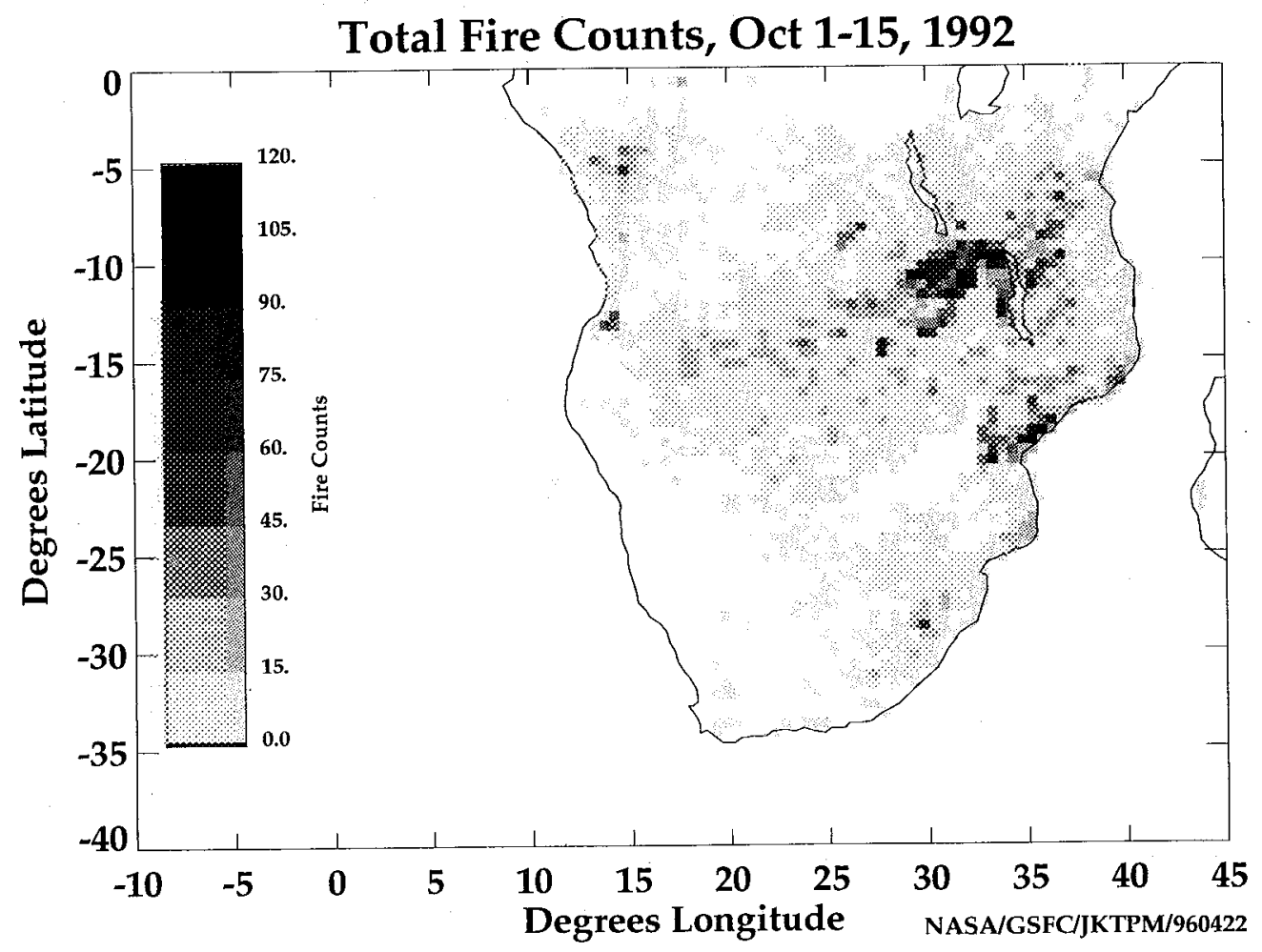

Figure 6. Satellite-derived fire counts for October 1-15, 1992 [Justice et al., this issue].

The fact that both South America and Africa apparently supply the Atlantic with $\mathrm{O}_{3}$ and $\mathrm{O}_{3}$ precursors explains the high $\mathrm{O}_{3}$ column over the ocean. The ozone amounts over South America, Africa, and the Atlantic can be used to estimate a regional budget for $\mathrm{O}_{3}$ from biomass burning. Table 4 gives the area for each region. We designate as $\Sigma$ (additional averaged tropospheric ozone) the tropospheric $\mathrm{O}_{3}$ beyond background level and convert to teragrams $\left(10^{12}\right.$ grams $)$ of ozone for each area (area in square centimeters) as follows:

$$
(\Sigma-26) \times 2.69 \times 10^{16} \times \text { area } \times 48 / 6.023 \times 10^{23}
$$

where $26 \mathrm{DU}$ is background tropospheric column $\mathrm{O}_{3}(1 \mathrm{DU}=$ $2.69 \times 10^{16}\left(\right.$ molecules $\left.\left./ \mathrm{cm}^{2}\right)\right), 48$ is the molecular weight of $\mathrm{O}_{3}$ in grams per mole, and $6.023 \times 10^{23}$ is Avogadro's number, in molecules per mole. This is the accumulated $\mathrm{O}_{3}$ budget above background which is a function of the rate of photochemical $\mathrm{O}_{3}$ production from biomass burning and biogenic precursors as well as the lifetime of $\mathrm{O}_{3}$.

We calculate a total ozone burden for southern Africa for October 6-21, 1992. Since this study does not extend south of $14^{\circ} \mathrm{S}$, we must estimate tropospheric $\mathrm{O}_{3}$ south of $14^{\circ} \mathrm{S}$ to find the total budget produced by biomass burning. From remote sensing data over Africa [Justice et al., this issue] fire counts north of $14^{\circ} \mathrm{S}$ are twice what they are south of $14^{\circ} \mathrm{S}$. It is reasonable to assume that the same ratio holds in South America (C. Justice, personal communication, 1994). For a band from $0^{\circ}$ to $30^{\circ} \mathrm{S}$ between Africa and South America, this results in a total tropospheric $\mathrm{O}_{3}$ burden for this region of $9.9 \mathrm{Tg}$ (Table 4). If an average $\mathrm{O}_{3}$ formation rate of $2-3 \mathrm{DU} / \mathrm{day}$ [Thompson et al., this issue (b)] is assumed, the $\mathrm{O}_{3}$ formation rate from South America, across the Atlantic, to Africa is 1.4 $\sim 2.1 \mathrm{Tg} /$ day, with about a 6-day lifetime $(9.9(\mathrm{Tg}) /\{1.4 \sim 2.1$
( $\mathrm{Tg} /$ day) $\}$ ). Therefore the burden of tropospheric $\mathrm{O}_{3}$ produced from biomass burning in October is $51 \mathrm{Tg}(9.9(\mathrm{Tg}) \times 1$ (month)/6 (days)).

In order to derive a total burden from southern tropical African and South American biomass burning, we have to calculate the burden in each month (June to September) relative to that in October. For this calculation we use the records of integrated tropospheric $\mathrm{O}_{3}$ in Brazzaville, Ascension Island, and Natal [Cros et al., 1992; Fishman et al., 1992]. These show tropospheric $\mathrm{O}_{3}$ beyond background level to be approximately the same in August through October, with October about 1.5 times greater in tropospheric $\mathrm{O}_{3}$ than in June and July. Thus we compute for the total burden of biomass-burning-derived tropospheric $\mathrm{O}_{3}$ (June to October) from South America, the Atlantic, and southern Africa:

$$
\begin{aligned}
51 & \times 3+2 / 3 \\
& \times\{9.9(\mathrm{Tg}) \times(2 \text { months }) /(6 \text { days })\} \approx 220 \mathrm{Tg} \mathrm{O}_{3}
\end{aligned}
$$

Because surface measurements of tropospheric $\mathrm{O}_{3}$ are lower and the period of biomass burning season in northern Africa (December to February) is shorter than those in southern Africa [Cros et al., 1991], the total burden of tropospheric $\mathrm{O}_{3}$ in northern Africa is probably less than in southern Africa.

Andreae [1991] suggests that the $\mathrm{O}_{3}$ burden from biomass burning over South America and Africa is $230 \mathrm{Tg} \mathrm{O} / \mathrm{yr}$ with an error of factor of 2. Lelieveld et al. [1996], in a global (threedimensional) model calculation of $\mathrm{O}_{3}$ sources and sinks, computes a net $\mathrm{O}_{3}$ loss in the tropics due to high $\mathrm{UV}$ insolation and humidity: via the $\mathrm{H}_{2} \mathrm{O}+\mathrm{O}\left({ }^{1} D\right)$ reaction, $\mathrm{O}_{3}$ is destroyed Biomass burning inputs do, however, result in formation of 144 $\mathrm{Tg} \mathrm{O}_{3} / \mathrm{yr}$. 


\subsection{Tropospheric $\mathrm{O}_{3}$ Over Western South America and the Pacific}

Plate 2 shows that averaged tropospheric column $\mathrm{O}_{3}(28$ DU) over the east Pacific Ocean is slightly higher than that $(26$ DU) over the central Pacific Ocean, but more in situ observations are required to say this with certainty. If there is elevated tropospheric $\mathrm{O}_{3}$ over the eastern Pacific due to transport from South America, it would not be as efficient as the transport from Africa to the Atlantic because of the high barrier of the Andes. These mountains also contribute to the very low $\mathrm{O}_{3}$ observed over western South America. The Pacific Exploratory Mission-Tropics (PEM-Tropics) aircraft mission, scheduled for August-October 1996, will build a tropospheric ozone climatology for the tropical Pacific, with one or two ozone sounding sites being added to Samoa.

A tropospheric $\mathrm{O}_{3}$ column as high as $40 \mathrm{DU}$ is observed near $140^{\circ} \mathrm{E}$, where northern Australia and New Guinea are located. This region is affected by biomass burning from these nations and from Indonesia and Borneo [Hurst et al., 1994]. The intensities in Plate 2 suggest that this area contributes much less to the tropical $\mathrm{O}_{3}$ budget than Africa or South America. The lowest tropospheric column $\mathrm{O}_{3}$ is observed from the Indian to the far western Pacific Ocean.

\section{Conclusion}

This paper continues a series of studies aimed at deriving the tropospheric $\mathrm{O}_{3}$ column in the tropics from high-density TOMS radiances. Errors inherent in archived TOMS $\mathrm{O}_{3}$ data have been corrected: cloud effects (cf analysis of Hudson and Kim [1994] with archived TOMS of Thompson et al. [1993]), inefficiency of lower tropospheric $\mathrm{O}_{3}$ retrieval [Hudson et al., 1995], and satellite attitude error and aerosols (this work). The present error analysis emphasizes the need to use the TOMS radiances in the high-density tapes to derive tropospheric column $\mathrm{O}_{3}$.

A new method has been developed to derive the timeaveraged stratospheric ozone field over the tropics, a necessary precursor to determining the tropospheric column ozone. From examination of the total ozone field, an underlying wave 1 pattern, which could be ascribed to a stratospheric or tropospheric wave, has been identified. For the period of October 6-21, 1992 (during the TRACE A experiment), the tropospheric ozone map based on a stratospheric wave assumption gives excellent agreement (within 10\%) with the DC-8 aircraft ozone data and with tropical ozone soundings at Brazzaville, Ascension Island, and Natal (Brazil). Further elucidation of the wave requires $\mathrm{O}_{3}$ profile measurements from surface to lower stratosphere. Our method is valid only in the tropics where stratospheric ozone is relatively invariant over severalweek periods of time. The fact that the sondes are 2-4 DU greater than our map suggests that we have overestimated stratospheric ozone by this amount, but it is within the uncertainty of the method. Beyond the tropics, derivation of accurate tropospheric $\mathrm{O}_{3}$ from TOMS requires detailed knowledge of the stratospheric ozone profile.

As expected, the main feature of tropospheric $\mathrm{O}_{3}$ during this period is the widespread maximum (total column $\mathrm{O}_{3} 40 \mathrm{DU}$ or more) extending from southern equatorial Africa across the Atlantic to South America. Examination of averaged winds and satellite-derived fire locations strengthens the case for a strong biomass burning component of this $\mathrm{O}_{3}$ feature. North of the equator regions of elevated tropospheric $\mathrm{O}_{3}$ are less uniform, which is consistent with biogenic sources, lightning at the
ITCZ, and lower levels of biomass burning (rainy season). Elevated $\mathrm{O}_{3}$ levels near Australia and New Guinea may signal biomass burning in that region.

Acknowledgments. This work was supported by the NASA Atmospheric Chemistry Modeling and Analysis Program (ACMAP), grant NAGW-1696 to the University of Maryland, and through ACMAP, EOS, and Tropospheric Chemistry Program funding to Goddard Space Flight Center. Thanks to J. Fishman (NASA Langley) for the ozone soundings, to C. Justice (University of Maryland) for the fire map, and to D. McNamara (Applied Research Corporation) for trajectory calculations. The uv-DIAL ozone data were provided courtesy of E. Browell via the GTE archive. We thank J. Ziemke (NASA Goddard Space Flight Center) for discussion of stratospheric wave dynamics in the tropics and the reviewers for comments.

\section{References}

Aerospace Engineering and Research Associates (AERA), Nimbus-7 attitude discrepancy analysis, Contract NAS 5-30115, 1990.

Andreae, M. O., Biomass burning: Its history, use, and distribution and its impact on environmental quality and global climate, in Global Biomass Burning, edited by J. S. Levine, pp. 3-21, MIT press, Cambridge, Mass., 1991

Andreae, M. O., J. Fishman, M. Garstang, J. G. Goldammer, C. $\dot{O}$ Justice, J. S. Levine, R. J. Scholes, B. J. Stocks, A. M. Thompson, B. van Wilgen, and the STARE/TRACE-A/SAFARI-92 Science team, Biomass burning in the global environment: First results from the IGAC/BIBEX field campaign STARE/TRACE-A/SAFARI-92, in Global Atmosphere-Biospheric Chemistry: The First IGAC Scientific Conference, edited by R. Prinn, pp. 83-102, Plenum, New York, 1994a. Andreae, M. O., B. E. Anderson, D. R. Blake, J. D. Bradshaw, J. E. Collins, G. L. Gregory, G. W. Sachse, and M. C. Shipham, Influence of plumes from biomass burning on atmospheric chemistry over the equatorial and tropical south Atlantic during CITE-3, J. Geophys. Res., 12,793-12808, 1994b.

Andrews, D. G., J. R. Holton, and C. B. Leovy, "Middle Atmosphere Dynamics," Academic, San Diego, Calif., 1987.

Baldy, S., G. Ancellet, M. Bessafi, A. Badr, and D. Lan Sun Luk, Field observations of vertical distribution of tropospheric ozone at the island of Reunion (southern tropics), J. Geophys. Res., this issue.

Bhartia, P. K., J. Herman, R. D. McPeters, and O. Torres, Effect of Mount Pinatubo aerosols on total ozone measurements from backscatter ultraviolet experiments, J. Geophys. Res, , 98, 18,547-18,554, 1993.

Browell, E. V., et al., Ozone and aerosol distributions and air mass characteristics observed over the South Atlantic basin during the burning season, J. Geophys. Res., this issue.

Cros, B. D., D. Nganga, R. A. Delmas, and J. Fontan, Tropospheric ozone and biomass burning in intertropical Africa, in Global Biomass Burning, edited by J. S. Levine, p. 143, MIT Press, Cambridge, Mass., 1991.

Cros, B. D., D. Nganga, A. Minga, J. Fishman, and V. Brackett, Distribution of tropospheric ozone at Brazzaville, Congo, determined from ozonesonde measurements, J. Geophys. Res., 97, $12,869-12,876,1992$

Fishman, J., Probing planetary pollution from space, Environ. Sci. Technol., 25, 612-621, 1991.

Fishman, J., and J. C. Larsen, Distribution of total ozone and stratospheric ozone in the tropics: Implications of the distribution of tropospheric ozone, J. Geophys. Res., 92, 6627-6634, 1987.

Fishman, J., C. E. Watson, J. C. Larsen, and J. A. Logan, The distribution of tropospheric ozone determined from satellite data, J. Geophys. Res., 95, 3,599-3,617, 1990.

Fishman, J., K. Fakhruzzaman, B. Cros, and D. Nganga, Identification of widespread pollution in the southern hemisphere deduced from satellite analysis, Science, 252, 1,693-1,696, 1991.

Fishman, J., V. G. Brackett, and K. Fakhruzzaman, Distribution of tropospheric ozone in the tropics from satellite and ozonesonde measurements, J. Atmos. Terr. Phys., 54, 589-597, 1992.

Fishman, J., J. M. Hoell Jr., R. D. Bendura, V. W. J. H. Kirchhoff, and R. J. McNeal Jr., The NASA GTE TRACE A experiment (September-October 1992): Overview, J. Geophys. Res., this issue (a). Fishman, J., V. G. Brackett, E. V. Browell, and W. B. Grant, Tropo- 
spheric ozone derived from TOMS/SBUV measurements during TRACE A, J. Geophys. Res., this issue (b).

Garstang, M., P. D. Tyson, R. Swap, M. Edwards, P. Kăllberg, and J. A. Lindesay, Horizontal and vertical transport of air over southern Africa, J. Geophys. Res., this issue.

Gregory, G. L., H. E. Fuelberg, S. P. Longmore, B. E. Anderson, J. E. Collins, and D. R. Blake, Chemical characteristics of tropospheric air over the tropical South Atlantic Ocean: Relationship to trajectory history, J. Geophys. Res., this issue.

Harris, G. W., F. G. Wienhold, and T. Zenker, Airborne observations of strong biogenic $\mathrm{NO}_{x}$ emissions from the Namibian savanna at the end of the dry season, J. Geophys. Res., this issue.

Hudson, R. D., and J. Kim, Direct measurements of tropospheric ozone using TOMS data, in Ozone in the Troposphere and Stratosphere, NASA Conf. Publ. 3266, edited by R. D. Hudson, 119-121, 1994.

Hudson, R. D., J. Kim, and A. M. Thompson, On the derivation of tropospheric column ozone from radiances measured by the total ozone mapping spectrometer, J. Geophys. Res., 100, 11,137-11,145, 1995.

Hudson, R. D., A. M. Thompson, and J. Kim, Annual cycle of tropical tropospheric ozone, Eos Trans. AGU., 77(17), Spring Meet. Suppl., 65,1996

Hurst, D. F., D. W. T. Griffith, and G. D. Cook, Trace gas emissions from biomass burning in tropical Australian savannas, J. Geophys. Res., 99, 16,441-16,456, 1994.

Justice, C. O., J. D. Kendall, P. R. Dowty, and R. J. Scholes, Satellite remote sensing of fires during the SAFARI campaign using NOAA AVHRR data, $J$. Geophys. Res., this issue.

Kim, J., The derivation of time-averaged and daily tropospheric column ozone from radiances measured by the Total Ozone Mapping Spectrometer: Intercomparison and Analysis, Ph.D. thesis, Univ. of Md., College Park, 1995.

Kirchhoff, V. W. J. H., J. R. Alves, F. R. da Silva, and J. Fishman, Observations of ozone concentrations in the Brazilian cerrado during the TRACE A field expedition, J. Geophys. Res., this issue.

Komhyr, W. D., S. J. Oltmans, P. R. Franchois, W. F. J. Evans, and W. A. Matthews, The latitudinal distribution of ozone to $35 \mathrm{~km}$ altitude from ECC ozonesonde observations, 1985-1987, in Ozone in the Atmosphere, Proceedings of Quadrennial Ozone Symposium 1988 and Tropospheric Ozone Workshop, edited by R. D. Bojkov and P. Fabian, pp. 147-150, A. Deepak, Hampton, Va., 1989.

Lelieveld, J., P. Crutzen, D. Jacob, and A. Thompson, Modeling of biomass burning influences on ozone, in Fire in Southern African Savanna: Ecological and Atmospheric Perspectives, edited by B. van Wilgen, M. O. Andreae, J. G. Goldammer, and J. A. Lindesay, Univ. of Witwatersrand, Johannesburg, in press, 1996.

Marenco, A., J. C. Medale, and S. Prieur, Study of tropospheric ozone in the tropical belt (Africa, America) from STRATOZ and TROPOZ campaigns, Atmos. Environ., 24A, 2823-2834, 1990.

McCormick, M. P., J. M. Zawodny, R. E. Veiga, J. C. Larsen, and P. H. Wang, An overview of SAGE I and II ozone measurements, Planet. Space Sci., 37, 1567-1586, 1989.

McPeters, R. D., et al., Nimbus-7 Total Ozone Mapping Spectrometer (TOMS) data products user's guide, NASA Ref. Publ., 1323, 1993.

Olson, J. R., J. Fishman, V. W. J. H. Kirchhoff, D. Nganga and B. Cros, Analysis of the distribution of ozone over the southern Atlantic region, J. Geophys. Res., this issue.

Pickering, K. E., et al., Convective transport of biomass burning emissions over Brazil during TRACE A, J. Geophys. Res., this issue.

Shiotani, M., and Hasebe, F., Stratospheric ozone variations in the equatorial region as seen in Stratospheric Aerosol and Gas Experiment data, J. Geophys. Res., 99, 14,575-14,584, 1994.
Sieber, C., J. H. Kim, R. D. Hudson, and A. M. Thompson, Timeaveraged tropospheric ozone derived from TOMS radiances: A comparison of maps for the tropical Atlantic from 1-15 Oct. 1989 and 1-15 Oct. 1992, Eos Trans. AGU, 76(17), Spring Meet. Suppl. 72, 1995.

Stanford, J. L., and J. R. Ziemke, Rossby-gravity waves in tropical total ozone, Geophys. Res. Lett., 20, 2239-2242, 1993.

Thompson, A. M., K. E. Pickering, D. P. McNamara, and R. D. McPeters, Effect of marine stratocumulus on TOMS ozone, J. Geophys. Res., 98, 23,051-23,057, 1993.

Thompson, A. M., K. E. Pickering, D. P. McNamara, M. R. Schoeberl, R. D. Hudson, J. H. Kim, E. V. Browell, V. W. J. H. Kirchhoff, and D. Nganga, Where did tropospheric ozone over southern Africa and the tropical Atlantic come from in October 1992? Insights from TOMS, GTE/TRACE A and SAFARI-92, J. Geophys. Res., this issue (a).

Thompson, A. M., et al., Ozone over southern Africa during SAFARI92/TRACE A, J. Geophys. Res., this issue (b).

Thompson, A. M., T. Zenker, G. E. Bodeker, and D. P. McNamara, Ozone over southern Africa: Patterns and influences, in Fire in Southern African Savanna: Ecological and Atmospheric Perspectives, edited by B. van Wilgen, M. O. Andreae, J. G. Goldammer, and J. A. Lindesay, Univ. of Witwatersrand, in press, 1996.

Tsuda, T., Y. Murayama, H. Wiryosumarto, S. Harijono, and S. Kato, Radiosonde observations of equatorial atmosphere dynamics over Indonesia, 1, Equatorial waves and diurnal tides, J. Geophys. Res., 99, 10,491-10,506, 1994.

Tyson, P. D., M. Garstang, R. J. Swap, E. V. Browell, R. D. Diab, and A. M. Thompson, Transport and vertical structure of ozone and aerosol distributions over southern Africa, in Biomass Buming and Global Change, edited by J. S. Levine, MIT Press, Cambridge, Mass., in press, 1996.

Watson, C. E., J. Fishman, and H. Reichle Jr., The significance of biomass burning as a source of carbon monoxide and ozone in the southern hemisphere tropics: A satellite analysis, J. Geophys. Res., $95,16,443-16,450,1990$.

Watson, C. E., J. Fishman, G. L. Gregory, and G. W. Sachse, A comparison of wet and dry season and CO over Brazil using in-situ satellite measurements, in Global Biomass Burning, edited by J. S. Levine, pp. 115-121, MIT Press, Cambridge, Mass., 1991.

Weller, R., R. Lilischkis, O. Schrems, R. Neuber, and S. Wessel, Vertical ozone distribution in the marine atmosphere over the central Atlantic Ocean $\left(56^{\circ} \mathrm{S}-50^{\circ} \mathrm{N}\right)$, J. Geophys. Res., 101, 1387-1399, 1996.

Zepp, R. G., W. L. Miller, R. A. Burke, D. A. B. Parsons, and M. C Scholes, Effects of moisture and burning on soil-atmosphere exchange of trace carbon gases in a southern African savanna, $J$. Geophys. Res., this issue.

Ziemke, J. R., and J. L. Stanford, Kelvin waves in total column ozone, Geophys. Res. Lett., 21, 105-108, 1994.

Ziemke, J. R., S. Chandra, A. M. Thompson, and D. P. McNamara, Zonal asymmetries in southern hemisphere column ozone: Implications of biomass burning, J. Geophys. Res., 101, 14,421-14,427, 1996.

R. D. Hudson, Department of Meteorology, University of Maryland, College Park, MD 20771. (e-mail: hudson@atmos.und.edu)

J. H. Kim, Earth System Science Laboratory, University of Alabama, Huntsville, AL 35899. (e-mail: jae@ozone.atmos.uah.edu)

A. M. Thompson, NASA Goddard Space Flight Center, Code 916, Greenbelt, MD 20771. (e-mail: thompson@gatorl.gsfc.nasa.gov)

(Received December 12, 1994; revised April 2, 1996; accepted April 2, 1996.) 